\title{
How does motherhood affect self-employment performance?
}

\author{
Pernilla Andersson Joona $(\mathbb{D}$
}

Accepted: 14 May 2017 / Published online: 7 June 2017

(C) The Author(s) 2017. This article is an open access publication

\begin{abstract}
This paper analyzes the timing between self-employment entry and first child birth among Swedish women, using register data for the cohort of women born between 1970 and 1975. We use longitudinal data, where we observe selfemployment entry, childbirths, and self-employment outcomes during the period 1995 to 2013. The main research question is whether women who have children when entering self-employment perform less well compared to women who do not have children at the time of self-employment entry. One reason to expect differences in outcomes is that childless women are less time constrained and could potentially invest more time in the business, which could affect outcomes. We find, contrary to our hypothesis, that women who had a child at the time of selfemployment entry have higher incomes, higher revenues and more employees in their firms, while we find no difference in the exit rate out of selfemployment.
\end{abstract}

Keywords Female entrepreneurship · Self-employment success $\cdot$ Children

JEL codes $\mathrm{L} 26 \cdot \mathrm{J} 13 \cdot \mathrm{M} 13$

P. A. Joona $(\bowtie)$

Swedish Institute for Social Research, Stockholm University,

SE-106 91 Stockholm, Sweden

e-mail: Pernilla.andersson.joona@sofi.su.se

\section{Introduction}

In most Western economies, female self-employment rates are lower than those of men. As a result, many governments want to increase female self-employment through various targeted projects. Sweden is no exception. The rationale behind such policies is that selfemployed individuals contribute to job creation and are important for economic growth. Women are assumed to be as good entrepreneurs as men, and they should be given equal opportunities to start a business. At the same time, there is a body of literature, primarily for Anglo-Saxon countries, that hypothesizes that selfemployment is a way for women to facilitate the combination of work and family. A number of survey studies, both for Sweden and other countries, report that it is less common among women to become self-employed as a career choice and more common to choose selfemployment for lifestyle reasons, particularly when the children are young, while men, to a larger extent, are driven by pecuniary motives. ${ }^{1}$ Studies exploring this idea find in general that there is a positive correlation between the presence of young children in the household and self-employment probabilities among women (Boden 1996, 1999; Budig 2006; Carr 1996; Hundley 2000; Lombard 2001; Wellington 2006). Two recent papers for Norway and Sweden also find a positive correlation between the presence of young children in the household and self-employment entry

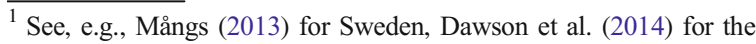
UK, and Burke et al. (2002) for the UK.
} 
(Rønsen 2014; Andersson Joona 2017) — this in spite of the existence of family-friendly policies that encourage labor force participation among mothers and fathers with young children. However, one difference found between Sweden and Anglo-Saxon countries is that self-employed women in Sweden spend more, or as much, time on market work as wage-earning women, while the opposite is true in many other countries (Gimenez-Nadal et al. 2012; Gurley-Calvez et al. 2009; Mångs 2013; Johansson Sevä and Öun 2015).

The relationship between self-employment and having children is complex, and most of the abovementioned studies do not pay particular attention to the direction of causality: the presence of children in the household could have an impact on selfemployment entry, but self-employment could also have an impact on fertility decisions. ${ }^{2}$ The direction of causality in this relationship has, however, been analyzed in a recent paper that uses an instrumental variable approach (Noseleit 2014). Here, it is found that family size appears to have a causal effect on self-employment but that self-employment does not affect family size. ${ }^{3}$

In the present paper, we ask novel questions to analyze the relationship between self-employment and fertility. The first question asked is related to the timing between self-employment entry and childbirth. Do women become self-employed before or after childbirth? The second question, which is also the main research question in the paper, is how the timing between self-employment entry and first child birth affects self-employment success. Becoming a successful entrepreneur in general requires much work, and much time needs to be invested in the business. This could be more difficult when having young children. At the same time, women who start their business while having young children might do it for other reasons than to become successful - it could be a way of facilitating the combination of work and family responsibilities.

It is a political goal to increase female self-employment, but not mainly for lifestyle reasons. Although this could be beneficial for the individual (e.g., easier to

\footnotetext{
2 The impact of self-employment on fertility has been analyzed in Broussard et al. (2015)

${ }^{3}$ It is worth noting that most previous studies focus on the impact of the presence of young children in the household, while Noseleit (2014) analyzes the impact of having more than two children, which is instrumented by the same sex of the two first siblings and twin births, on self-employment
}

combine family and work), it would perhaps not be efficient for society if labor market productivity decreases when becoming self-employed. Therefore, it is important to learn more about whether self-employment performance differs depending on the circumstances under which the firm was started-did the (female) founder have children or did she start the firm before having children? We analyze six different measures of self-employment performance: income, being a top income earner, net revenues, corporate form, having employees, and the exit rate. The two last measures can be particularly important for the overall impact of selfemployment on employment growth. By employing coworkers, the self-employed contribute to job creation, and the exit rate out of self-employment is related to the unemployment risk among the self-employed themselves.

We find, contrary to our expectations, that women who started their business while having children do not perform worse compared to women who became self-employed when they did not have children. In terms of annual earnings and revenues, we find that women who had children at the start perform better, while we find no difference in the exit rate. There is also some evidence that women who had children when entering self-employment have more employees. We suggest four different explanations for these results. Firstly, women who did not have children when entering self-employment postpone childbearing and have their children later. This then mechanically leads to this group of women, on average, having younger children during the years in which we observe self-employment outcomes. Moreover, the presence of young children has a negative impact on selfemployment performance. Secondly, becoming a mother in general can mean that one becomes more efficient at work, independently of whether one is a wage-earner or self-employed. Thirdly, so-called mamatreneurs, a group of self-employed women, who, as a result of their motherhood, discover market opportunities that are related to children or motherhood itself, come up with better business ideas and as a result perform better. Fourthly, there is a selection of more motivated and more ambitious women who manage to start a business when they have (young) children. It is clear from this that we do not claim to have estimated the causal effect of having children at the time of self-employment entry on subsequent self-employment performance. To do this, we need some source of exogenous variation in the timing between self-employment entry and first child births. 
In the empirical analysis, we use Swedish register data for the cohorts of women born between 1970 and 1975. We construct a balanced panel and observe selfemployment entry and childbirths for each year in the period 1995 to 2013. We exclude women who are selfemployed in 1995 and women who already had a child in 1995. Since the sample is fairly young in 1995 (2025 years), we believe that we are likely to observe the first entry into self-employment and the birth of the first child. Having data on six full cohorts of women and being able to follow them over a period of 19 years gives us a unique opportunity to study self-employment entry and fertility choices and how they are related to each other.

Even though the focus of the paper is on selfemployment outcomes, we also look at the impact of having young children on self-employment entry. Previous literature has found a positive correlation between having young children and entering self-employment, and this is also what we find in our sample. In addition, we see that nearly $70 \%$ of women in these cohorts who were self-employed at some point between 1996 and 2013 entered self-employment while being a mother, and hence, approximately $30 \%$ entered selfemployment when they did not have any children.

The remainder of the paper is structured as follows: in Sect. 2, the pros and cons of entering selfemployment before and after childbirth are discussed, and we discuss how we expect this to affect outcomes; in Sect. 3, the data and descriptive statistics are presented; in Sect. 4, the results on self-employment entry are presented; in Sect. 5, the results on self-employment performance are presented; and in Sect. 6, the results are summarized, and some conclusions are drawn and their implications discussed.

\section{Hypotheses regarding the timing between self-employment entry and child births and how we expect this to affect outcomes}

After graduating and being on the verge of entering the labor market, an individual has to make a number of choices. In this paper, we are interested in the choice of self-employment entry and fertility choices. A woman could enter self-employment for the first time before or after having children. If and when each of these events will take place will be influenced by a number of factors, and we will not go through previous research on factors affecting self-employment entry and fertility choices in general. $^{4}$

\subsection{Self-employment entry before child birth}

Self-employment is generally correlated with longer working hours than wage-employment (see, e.g., Andersson 2008; Benz 2008). Therefore, those who want to be self-employed would have incentives to start a business before having children, since they will be more time constrained when they have young children at home. Differences in working time between selfemployment and wage-employment, particularly during the start-up phase, are likely to be important factors for women who choose self-employment as a career choice to develop a business idea or to earn more money than in wage-employment.

Self-employment is also assumed to be a more uncertain form of employment with a more insecure level of income, and it is believed to be correlated with a higher risk than taking a wage-earning job. ${ }^{5}$ Hence, it might be less worrisome to start a business before having babies, since one has no children to support financially.

Anxo and Ericson (2015) analyze differences in parental leave during the child's first 2 years between selfemployed and wage-earning parents in Sweden. They find that both self-employed mothers and fathers take fewer days of parental leave. For mothers, they argue that one explanation is that women with a stronger commitment to market work are more likely to choose self-employment even if they plan for family and children. Being self-employed when having young children would give them a better opportunity to combine market work and family responsibilities even when the children are very young (e.g., below 1 year). According to this argument, women who have preferences for working while the child is young might choose self-employment already before childbirth.

If women in fertile ages who plan for children but do not yet have any and who choose self-employment are positively selected from the pool of all women in these

\footnotetext{
${ }^{4}$ For previous research on factors affecting self-employment entry, see, e.g., Simoes et al. (2015) for a general overview and Taniguchi (2002) for an analysis of determinants of women's entry into selfemployment.

${ }^{5}$ See Ekelund et al. (2005) and references therein for a discussion of why self-employment can be assumed to be a more risky occupational choice than being a wage-earner.
} 
age groups, then we would expect them to have better labor market outcomes as mothers compared to wageearners. This type of selection will, however, not lead to any predictions about how women who enter selfemployment before childbirth will perform compared to women who enter self-employment after childbirth. It is possible that women who enter self-employment after childbirth also are positively selected from the pool of wage-earners who have (young) children. Anxo and Ericson (2015) do not make any inference about how women who already have children are selected into selfemployment.

\subsection{Self-employment entry after childbirth}

Even though self-employed, on average, spend more time on market work than wage-earners, selfemployment is also assumed to be a more flexible form of employment than wage-employment. As selfemployed, it is easier to decide how much to work and on what days of the week. These qualities of selfemployment are assumed to increase the demand for self-employment among women with young children. A number of previous studies find a positive correlation between self-employment and the presence of young children in the household. Hence, we expect that all else being equal, self-employment entry should be higher among women who already have children compared to women who do not have any children.

A second reason for becoming self-employed after childbirth is that the parental leave benefits in Sweden are strongly dependent on previous income, and incomes among the self-employed are, on average, lower than among wage-earners. In the Swedish parental leave system, a pre-birth earnings level is calculated for all expecting mothers. For wage-earners, the employer sends information on actual wages to the Social Insurance Agency. For the self-employed, the procedure is more complicated. The aim of the social insurance system is to create equality between different employment forms so that, for example, the self-employed will not be disadvantaged in the social security system. The system has been criticized for not being very transparent and for being difficult to fully understand. To simplify, it can be said that pre-birth earnings are based on the average income in the firm during the three previous years. An important rule is, however, that this income never can exceed the income a comparable wage-earner receives, that is, a wage-earner performing a similar job. If the firm is in the start-up phase, which normally lasts between 1 and 3 years, the income can be lower than what "normally" would be the case. Then, the actual income can be ignored, and case workers at the Social Insurance Agency directly determine a comparable income and use this as an estimate of pre-birth earnings. It is difficult to say exactly how the setup of the system affects women's incentives to become self-employed, but one possible effect is that women postpone self-employment entry until after child birth if they anticipate that parental leave benefits will be negatively affected by selfemployment.

Actual pre-birth earnings might also have a direct effect on fertility, not only via its impact on parental insurances. Many couples might wait until they have stable economic circumstances to have children, since better economic resources generally mean better conditions for taking care of a child. Andersson (2000), using Swedish data, finds that a lower income prior to childbirth has a negative effect of first birth rates.

To sum up, some women have no preference for becoming self-employed, no matter their family situation. But among those who do have this preference, the presence of children could be important. There are reasons to become self-employed both before and after childbirth, and it is likely that the motives for women to become self-employed differ depending on the presence of children. This, in turn, might affect outcomes.

\subsection{How does the presence of children at the time of self-employment affect self-employment outcomes?}

Our initial hypothesis was that the circumstances, under which the business was started, particularly if the women were childless or had children, will have an effect on subsequent self-employment performance. But the direction the effect will go is an empirical question. Based on previous research, we have reasons to expect that women who are childless when entering selfemployment will perform better.

It is well documented that mothers earn less than women without children among wage-earners, i.e., there is a so-called motherhood wage penalty. ${ }^{6}$ However, the existence of such a relationship has not been confirmed for the Nordic countries, although one clearly observes a drop in earnings when the child is born (Gash 2009). It

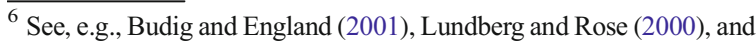
Waldfogel (1998).
} 
is estimated that earnings catch up in the long run (Angelov and Karimi 2012). Less is known about the existence of such a gap among self-employed women. Hundley $(2000,2001)$ analyzes the effects of marriage and children on self-employment earnings using US data (NLS-72). He finds that both marriage and children have a negative impact on self-employment earnings among women, while it is positively related to selfemployment earnings among men. He also finds that earnings among wage-earners are much less sensitive to both marital status and family size (Hundley 2000).

Marshall and Flaig (2014) use a nationally representative dataset for the US to analyze the association between marriage and children and self-employment earnings among women. Unlike many previous papers, but similar to the present study, they restrict the sample to self-employed women and compare earnings between married and single women. They hypothesize that married women will have lower earnings. In accordance with their hypothesis, they find that being married and having children is negatively correlated with selfemployment earnings.

Williams (2004) studies the effects of child care activities on self-employment duration in Europe and finds, in accordance with the expectation, that time spent on child care decreases duration in self-employment.

These are highly relevant results for the research question asked in the present paper. Although we include controls for contemporaneous fertility, i.e., the number of children in the same year as the outcomes are measured, we focus more on the impact of having children at the time of self-employment entry.

Analyzing self-employment survival of men and women in Canada, Rybczynski (2015) finds that the probability of exiting self-employment for women is increasing in the number of children below 15 years of age, but for men, the number of children has no impact on business survival.

Although based on a small sample of self-employed, Rey-Martí et al. (2015) find that women who state that they became self-employed to pursue a better work-life balance are less likely to succeed. Hughes (2006) also finds indications that women who state that they became self-employed for "work-family" reasons have lower incomes from self-employment than those having "classic" motives such as independence, challenge, and financial independence. Burke et al. (2002) do, however, find that non-pecuniary motives to enter selfemployment have a positive impact on performance for males, and they find no evidence that women entering self-employment for this reason perform worse, or better, than women who enter for other reasons.

\subsection{The impact of other factors on self-employment} success

Self-employment success can be measured in several ways. Income from self-employment, exit and survival rates, and job and wealth creation are some commonly studied outcomes. Outcomes may be affected by many different factors, such as age, education, experience, marital status, region, country of birth, and macroeconomic variables such as unemployment and GDP. In the following section, we provide a brief overview of what previous studies have found about these relationships. ${ }^{7}$ The fact that different factors might affect different outcomes differently makes the overview complex.

Many previous studies have looked at the importance of wealth or liquidity constraints, both for selfemployment entry and for success (see, e.g., HoltzEakin et al. 1994; Hurst and Lusardi 2004; Rybczynski 2015; Taylor 1999). The results from these studies are somewhat mixed. There is no information on wealth in the dataset used for the analysis in this paper. I will therefore not go into more detail about the importance of this variable.

\subsubsection{Self-employment earnings}

When self-employment performance is analyzed in terms of earnings, the variable that has received the most attention is education. van der Sluis et al. (2008) review empirical studies of the impact of formal schooling on self-employment performance. They conclude that formal education appears to increase self-employment earnings. They also conclude that the effect of education on earnings is smaller for self-employed than for wageearners in Europe, while the opposite is true in the USA. Another interesting conclusion is that self-employed women seem to benefit more from education compared to their male counterparts. Only looking at selfemployed women, Marshall and Flaig (2014) also find a positive impact of education on earnings.

\footnotetext{
${ }^{7}$ See Parker (2004) and Millán et al. (2012) for extensive overviews of the literature on the determinants of self-employment performance, particularly entrepreneurial survival and exit.
} 


\subsubsection{Survival}

One of the most studied self-employment outcomes is the exit rate out of self-employment (see, e.g., Taylor 1999; Millán et al. 2012). Previous results suggest a non-linear effect of age on the exit rate. Exit rates seem to be high in the youngest age group, but it also appears that the risk of exiting increases after age 40-50 years (Taylor 1999; Millán et al. 2012).

Formal education appears to have mixed effects on self-employment survival. The correlation between education and survival rates partly depends on whether all exits are studied together or whether exits are divided depending on destination, i.e., wage-employment or unemployment. Education is also likely to affect the exit rate differently over the business cycle. There are some indications that those self-employed with higher education are more likely to exit in economic booms, probably due to better outside options. In an economic recession, exit rates are lower among those with higher education (Kangasharju and Pekkala 2002). Taylor (1999) finds that qualifications are weakly correlated with exit rates, and it is suggested that formal qualifications do not need to be a good predictor of self-employment success. Millán et al. (2012), on the other hand, find a positive impact of formal education on survival in self-employment. After controlling for selection into selfemployment and ability, Asoni and Sanandaji (2016) find no impact of college education on business survival in the USA.

Previous research suggests that labor market experience prior to self-employment is an important determinant of business success. Unemployment experience increases exit rates, while previous experience in selfemployment or wage-employment decreases the risk of exiting (Taylor 1999; Millán et al. 2012).

There is a large body of literature looking at selfemployment among immigrants and that analyzes both entry and exit rates. Andersson Joona (2010) finds that immigrants in Sweden are more likely to exit selfemployment to unemployment, while natives are more likely to exit self-employment to wage-employment. Aldén and Hammarstedt (2015) report similar results. Fairlie and Robb (2007) find that black-owned businesses in the USA are less successful than businesses owned by whites. They conclude that an important factor in explaining these differences is the lack of experience of working in family-owned businesses among blacks. This is because it is less common among black business owners to have self-employed family members.

The unemployment rate could affect business survival in two ways. Exits from self-employment could increase in an up-turn, since the number of outside options increase, i.e., it will be easier to gain wage-employment. But exits could also decrease when the economy is booming and unemployment is low, since business opportunities might improve. The evidence on this is mixed. Taylor (1999) finds that unemployment at the time of self-employment entry is positively related to the exit rate, while Lin et al. (2000) find no impact of unemployment on the exit rates.

\subsubsection{Job creation}

Burke et al. (2002) use job creation as a measure of self-employment performance. They find that professional qualifications are not significantly related to job creation among female entrepreneurs, while it is positively correlated among males. Henley (2005) also analyzes job creation by the self-employed. He uses housing wealth as a measure of financial capital and finds that it is positively correlated with small business job creation. Having self-employed parents, which is a measure of entrepreneurial capital, is also positively correlated with job creation, particularly if the parents employed others. Education also seems to be positively correlated with job creation, while foreign background, for example, has no significant impact.

\section{Data and descriptive statistics}

\subsection{Data and sample restrictions}

We use Swedish register data for the cohorts of women born in 1970 to 1975 who lived in Sweden consecutively during the 19 years for which we have data: 1995 to $2013^{8}(N=310,567)$. This means that we observe them from when they are 20-25 years old in 1995 to when they are 3843 years old in 2013. We exclude women who

\footnotetext{
${ }^{8}$ We exclude individuals who immigrated after 1995 and individuals who emigrated during the observation period. This results in a balanced panel.
} 
were self-employed in $1995(N=2062)$ and women who already had a young child in 1995 $(N=64,500)$. The reason for this is that we want to observe first self-employment entry and first child births. Imposing these restrictions means that our working sample consists of 244,005 individuals whom we observe for 19 consecutive years. In this cohort, $10.7 \%(N=26,009)$ enter selfemployment at some point during the observation period. This is the group we include in the main analysis. In terms of survival analysis, this means that we exclude all right-censored observations, i.e., those who never entered self-employment during our observation period. The main purpose of this paper is not to estimate the impact of various covariates on self-employment entry per se but to analyze the timing between self-employment and childbirth among a group of women who at some point enter self-employment. Therefore, the analysis is restricted to a sample that at some point experienced one or more spells of self-employment. We are aware of the fact that if we wanted to draw inferences about the whole population, not including censored observations would lead to biased estimates.

The majority of the sample, $56 \%$, experienced one spell of self-employment during the observation period, while $30 \%$ had two spells and $10 \%$ had three spells. Approximately $3 \%$ had four or more spells of selfemployment. The average total time of selfemployment was 7.7 years. The overall selfemployment rate among women in Sweden was 5\% in 2013; hence, there is a non-negligible share in our cohort who entered self-employment.

\subsection{Variables and descriptive statistics}

Individuals are defined as self-employed if the largest source of income in November was from self-employment. Statistics Sweden, however, multiplies selfemployment incomes by a factor of 1.6 , since selfemployment incomes are generally lower. This is the definition used by Statistics Sweden in their employment register. It is possible, and not uncommon, that those defined as self-employed also receive some incomes from wage-employment during the year. Since we use annual data, this can be due to a self-employed person also being a wage-earner during parts of the year or it can be due to their being so-called combiners, i.e., they are both wage-earners and self-employed at the same time, combining two part-time jobs into one fulltime, and sometimes more than full-time job. Here, we only use the broader definition so that an individual is either self-employed or a wage-earner. Our definition of self-employment includes self-employed with unincorporated and incorporated firms. From the descriptive statistics presented in Table 1, we see that between $21 \%$ (women who did not have children when entering self-employment) and 30\% (women who had children when entering self-employment) had an incorporated firm at the start. Hence, most firms are unincorporated firms. These corporate forms differ with respect to what extent the individual is responsible for the financial situation of the firm. In an unincorporated firm, the owner is personally responsible for the finances, while in an incorporated firm, the owner has limited liability. If the firm is closed down and there are debts, an owner of an incorporated firm is personally responsible for these debts, while during normal circumstances, an owner of an incorporated firm only loses the invested capital. Another difference is the requirement of a sizable capital investment to start up an incorporated firm. The type of business one plans to start up and one's willingness to take risks are factors that influence the choice of corporate firm. For example, if the firm has employees and/or has large assets in the form of natural resources or real estate, then it would be preferable to have an incorporated firm.

In the first part of the empirical analysis, we look at the impact of having young children on selfemployment entry. This is not the main research question of the paper but should been seen as a description of the particular sample analyzed in this paper. Do we, as most previous papers, find a positive correlation between having young children and self-employment entry in this sample as well? In the self-employment equation, we use two measures of children: whether there are young children living in the household in period $t-1$, where a young child is defined as not older than 10 years $^{9}$ (yes/no), and the number of children in the household. To analyze the impact of family size, we include dummy variables for one, two, three, four, and more than four children and use women with no children as the reference group. We focus on self-employment

\footnotetext{
${ }^{9}$ We have also estimated all regressions defining "young children" as children between 0 and 3 years, and the results are very similar to the ones presented in the paper.
} 
Table 1 Descriptive statistics. Characteristics of women who enter self-employment before and after childbirth

\begin{tabular}{|c|c|c|c|c|c|}
\hline & $\begin{array}{l}\text { No children when } \\
\text { entering } \\
\text { self-employment }\end{array}$ & $\begin{array}{l}\text { No children when entering } \\
\text { self-employment but have } \\
\text { children later }\end{array}$ & $\begin{array}{l}\text { Have children when } \\
\text { entering } \\
\text { self-employment }\end{array}$ & $\begin{array}{l}\text { Difference } \\
1(3)-(1)\end{array}$ & $\begin{array}{l}\text { Difference } 2 \\
(3)-(2)\end{array}$ \\
\hline \multicolumn{6}{|l|}{ Fertility } \\
\hline Age at first childbirth & - & 33.8 & 29.2 & - & $4.5^{* * *}$ \\
\hline $\begin{array}{l}\text { Time between self- } \\
\text { employment and } \\
\text { childbirth }\end{array}$ & - & 4.4 years & 6.5 years & - & $-2.1^{* * *}$ \\
\hline \multicolumn{6}{|c|}{ Number of children in the household in 2013} \\
\hline No children & 47.7 & 3.1 & $4.5^{\mathrm{a}}$ & $43.2 * * *$ & $-1.4 * * *$ \\
\hline One child & 19.1 & 35.1 & 15.7 & $3.4 * * *$ & $19.5^{* * *}$ \\
\hline Two children & 27.3 & 50.7 & 54.0 & $-26.6 * * *$ & $-3.2 * * *$ \\
\hline Three children & 5.3 & 9.8 & 21.0 & $-15.8 * * *$ & $-11.2^{* * *}$ \\
\hline More than three children & 0.6 & 1.2 & 4.8 & $-4.2 * * *$ & $-3.6^{* * *}$ \\
\hline \multicolumn{6}{|c|}{ Characteristics at the time of entry } \\
\hline Age (std.dev) & $31.8(5.2)$ & $29.3(4.1)$ & $35.7(4.0)$ & $3.9 * * *$ & $6.4 * * *$ \\
\hline \multicolumn{6}{|l|}{ Age group } \\
\hline $20-25$ & 13.2 & 20.6 & 1.0 & $-12.2 * * *$ & $-19.6^{* * *}$ \\
\hline $26-30$ & 28.2 & 39.9 & 10.2 & $-18.0 * * *$ & $-29.7 * * *$ \\
\hline $31-35$ & 32.2 & 31.8 & 33.5 & $1.3^{* *}$ & $1.7^{* *}$ \\
\hline $36-43$ & 26.4 & 7.6 & 55.3 & $28.9 * * *$ & $47.6^{* * *}$ \\
\hline \multicolumn{6}{|l|}{ Marital status } \\
\hline Married & 14.7 & 16.2 & 59.6 & $44.9 * * *$ & $43.4^{* * * *}$ \\
\hline Single & 81.3 & 81.0 & 34.5 & $-46.8 * * *$ & $-46.5^{* * *}$ \\
\hline Other & 4.0 & 2.7 & 5.8 & $1.8^{* * *}$ & $3.1 * * *$ \\
\hline \multicolumn{6}{|l|}{ Education } \\
\hline Primary school & 6.1 & 5.6 & 5.0 & $-1.1 * * *$ & $-0.6^{*}$ \\
\hline Upper secondary school & 48.6 & 51.2 & 47.4 & $-1.2^{*}$ & $-3.8 * * *$ \\
\hline University & 44.6 & 42.6 & 46.8 & $2.2 * * *$ & $4.2 * * *$ \\
\hline Post-graduate studies & 0.6 & 0.4 & 0.8 & 0.02 & $0.4^{* *}$ \\
\hline Missing information & 0.1 & 0.1 & 0.1 & 0.0 & 0.0 \\
\hline \multicolumn{6}{|l|}{ County of residence } \\
\hline Stockholm & 36.4 & 37.4 & 31.1 & $-5.3 * * *$ & $-6.4 * * *$ \\
\hline Malmoe & 12.3 & 11.4 & 13.2 & $0.9^{* *}$ & $1.8^{* *}$ \\
\hline Gothenburg & 15.4 & 15.7 & 15.2 & -0.2 & -0.1 \\
\hline Other & 35.9 & 35.4 & 40.6 & $4.7 * * *$ & $5.2 * * *$ \\
\hline \multicolumn{6}{|l|}{ Region of birth ${ }^{\mathrm{b}}$} \\
\hline Sweden & 91.6 & 92.6 & 91.4 & -0.2 & $-1.2 * * *$ \\
\hline Western country & 1.7 & 1.4 & 1.6 & 0.1 & 0.2 \\
\hline Non-Western country & 6.7 & 6.0 & 7.0 & 0.3 & $1.0^{* *}$ \\
\hline Incorporated firm at start & 20.7 & 21.2 & 29.6 & $8.9^{* * *}$ & $8.4^{* * * *}$ \\
\hline \multicolumn{6}{|l|}{ Industry } \\
\hline $\begin{array}{l}\text { Retailing, information, } \\
\text { communication, hotel, } \\
\text { and restaurants }\end{array}$ & 17.4 & 15.7 & 21.2 & $3.8^{* * *}$ & $5.5^{* * * *}$ \\
\hline $\begin{array}{l}\text { Financial and business } \\
\text { services }\end{array}$ & 27.7 & 27.4 & 26.7 & -0.9 & 0.7 \\
\hline $\begin{array}{l}\text { Personal and cultural } \\
\text { services }\end{array}$ & 29.7 & 31.4 & 20.6 & $-9.1 * * *$ & $-10.8^{* * *}$ \\
\hline Other & 14.2 & 12.7 & 20.2 & $5.9 * * *$ & $7.5^{* * * *}$ \\
\hline
\end{tabular}


Table 1 (continued)

\begin{tabular}{|c|c|c|c|c|c|}
\hline & $\begin{array}{l}\text { No children when } \\
\text { entering } \\
\text { self-employment }\end{array}$ & $\begin{array}{l}\text { No children when entering } \\
\text { self-employment but have } \\
\text { children later }\end{array}$ & $\begin{array}{l}\text { Have children when } \\
\text { entering } \\
\text { self-employment }\end{array}$ & $\begin{array}{l}\text { Difference } \\
1(3)-(1)\end{array}$ & $\begin{array}{l}\text { Difference } 2 \\
(3)-(2)\end{array}$ \\
\hline Missing information & 11.0 & 12.8 & 11.3 & 0.3 & $-1.5 * * *$ \\
\hline \multicolumn{6}{|c|}{ Characteristics prior to self-employment entry } \\
\hline \multicolumn{6}{|c|}{ Labor market status } \\
\hline Wage-employment & 66.9 & 66.6 & 74.1 & $7.2 * * *$ & $7.5 * * *$ \\
\hline Education & 7.8 & 8.5 & 4.6 & $-3.2 * * *$ & $-3.9 * * *$ \\
\hline Unemployed & 9.2 & 10.3 & 5.8 & $-3.4 * * *$ & $-4.5^{* * *}$ \\
\hline Parental leave & 0.0 & 0.0 & 8.5 & $8.5 * * *$ & $8.5^{* * *}$ \\
\hline Other & 16.1 & 14.6 & 7.0 & $-9.1 * * *$ & $-7.6^{* * *}$ \\
\hline $\begin{array}{l}\text { Earnings (Swedish crowns, } \\
\text { SEK) }\end{array}$ & 144,745 & 142,260 & 147,084 & 2338 & $4823^{*}$ \\
\hline \multicolumn{6}{|c|}{ Self-employment outcomes (average over all years) } \\
\hline Income (SEK) & 157,179 & 165,307 & 158,317 & 1137 & $-6990 * * *$ \\
\hline 10th percentile & 8.5 & 8.0 & 11.0 & $2.5^{* * * *}$ & $2.9 * * *$ \\
\hline Incorporated firm & 22.0 & 22.5 & 31.2 & $9.2 * * *$ & $8.8^{* * *}$ \\
\hline \multicolumn{6}{|l|}{ Firm size } \\
\hline $\begin{array}{l}\text { Number of employees } \\
\text { (mean) }\end{array}$ & 7.3 & 6.6 & 16.4 & $9.1 * * *$ & $9.8 * * *$ \\
\hline No employees & 56.0 & 55.9 & 45.4 & $-10.6 * * *$ & $-10.5 * * *$ \\
\hline $1-5$ employees & 18.8 & 5.9 & 23.8 & $5.0 * * *$ & $1.7 * * *$ \\
\hline 6-20 employees & 5.3 & 19.2 & 7.5 & $2.2 * * *$ & $4.1 * * *$ \\
\hline More than 20 employees & 19.9 & & 23.3 & $3.4 * * *$ & \\
\hline Net revenues (SEK) & 8131 & 8964 & 18,980 & $10,848^{* * *}$ & $10,016^{* * *}$ \\
\hline Exits from self-employment & 16.7 & 14.0 & 24.0 & $7.3 * * *$ & $9.3 * * *$ \\
\hline Total number of years in SE & 9.1 & 10.1 & 6.9 & $-2.2 * * *$ & $-3.2 * * *$ \\
\hline Number of individuals & 8428 & 4539 & 17,581 & & \\
\hline
\end{tabular}

$* p<0.1 ; * * p<0.05 ; * * * p<0.01$

${ }^{\text {a }}$ Some of these women have children older than 15 years living in the same household. We use information on the number of children living in the same household in a certain year. There are cases where a woman gives birth to a child but a few years later is observed to no longer live in a household with children. This could happen if the parents separate and the children live with the father, if the children are taken into custody by the social authorities, or if the children are deceased. These cases are rare, but since we use a large sample, some of these cases are included.

${ }^{\mathrm{b}}$ The share of immigrants in the sample is low since we require that an individual has lived in Sweden consecutively during the years 1995 to 2013. Western countries: The Nordic countries, EU15, and North America. Non-Western countries: Europe (except the Nordic countries and EU15), Africa, South America, and Asia.

entry during the years when women are in their fertile ages. Our main sample is restricted to those who enter self-employment at some point during the 18-year observation period of 1996 to $2013 .{ }^{10}$ However, not all women in our sample became mothers during the observation period. In 2013, they were between 38 and 43 years old; hence, some women will have had children

\footnotetext{
${ }^{10}$ Those who are self-employed in 1995 are excluded from the analysis; hence, we observe outcomes for those who are self-employed starting from 1996.
}

after our observation period. Among women who became self-employed before childbirth, nearly $48 \%$ did not have any children in 2013.

\subsubsection{Variables measured at the time of self-employment entry}

The key question addressed in this paper is whether the presence of (young) children at the time of selfemployment entry affects subsequent self-employment 
success. In Table 1, we present some descriptive statistics for the two groups of women. This is shown in columns 1 and 3 . In column 2, we present sample means for women who did not have a child at self-employment entry but who became mothers at some point afterwards during our observation period. As can be seen from column 1 , nearly $48 \%$ remained childless throughout the whole time we observe them. In columns 4 and 5, we present the difference in sample means between the groups.

The majority, nearly $70 \%$, entered self-employment after childbirth. Entering self-employment before or after childbirth is highly correlated with age and marital status at the time of self-employment entry. Women who enter self-employment after childbirth were, on average, 35.7 years when they became self-employed, and nearly $60 \%$ were married. The age at the time of selfemployment entry in the other group was 31.8 years, and only $15 \%$ were married. Since being married means that a marriage is officially recorded, the category "single" also includes cohabiting women. The mean age at the first marriage was 33.2 years among Swedish women in 2014 (SCB 2015). This implies that the mean age of women who enter self-employment after child birth is slightly above the mean age at first marriage, while the mean age of those who did not have children when becoming self-employed is slightly below the mean. We measure these variables, which are constant over time, at the time of self-employment entry and not in the year when the outcomes are measured. Country of birth is also constant over time.

\subsubsection{Variables measured before self-employment entry}

We want to include controls for labor market status 1 year prior to self-employment entry in the outcome regressions. This is a crude way of controlling for push/pull factors that may have affected the decision to enter self-employment and subsequent self-employment performance. Having been unemployed before entering self-employment could imply that one is more likely to choose self-employment out of necessity. On the other hand, having been employed as a wage-earner before self-employment could indicate that self-employment entry is opportunity driven. We define five different labor market states: wage-earner, in education, unemployed, parental leave, and a residual category. From Table 1, we see that the majority in both groups were employed as wage-earners the year before entering self- employment. Among those who entered selfemployment before having children, none were on parental leave, while $8.5 \%$ in the other group entered selfemployment from parental leave.

We also include controls for annual labor earnings 1 year prior to self-employment. This is an aggregate measure of labor earnings received during the year. Variations will hence be due to variations both in working time over the year and in wages. Earnings are actual earnings measured in SEK; hence, those with zero earnings are also included. All earnings are expressed in 2013 prices. Comparing mean earnings 1 year prior to self-employment entry, we see that there are small and barely significant differences between the groups at the $10 \%$ level of significance. Annual earnings are approximately 147,000 SEK (approx. €17,000) for women who had children before self-employment entry and 145,000 SEK (approx. €16,860) for women who were childless when entering self-employment. If earnings are seen as an approximation of abilities, women in the two groups appear to be similar.

\subsubsection{Variables measured in the same year as the outcomes $^{11}$}

County of residence (four groups: the three largest city districts and the rest of Sweden) and education are measured the same year as the outcome. From Table 1, we see that the groups are similar both with respect to education and county of residence.

We also include controls for the presence of young children in the household, defined as children up to the age of 10 years, and the total number of children in the household in the same year as when outcomes are measured. In general, we expect that these factors are important for explaining labor market outcomes, and we will see that the inclusion of these variables in the regressions has a large impact on the estimate of whether the women had children or not when entering selfemployment. Women who became self-employed when not having children appear to have postponed childbirth and, hence, are more likely to have young children when the outcomes are measured. This can be seen from the fact that the age upon having the first child differs

\footnotetext{
${ }^{11}$ For simplicity, descriptive statistics for these variables are presented for the year of self-employment entry. This gives us an idea of how the groups differed at the time of self-employment entry. In the regressions, however, they are measured for the same years as the outcome and can thus vary over time.
} 
between the groups: women who became self-employed after childbirth were, on average, 29.2 years old when they had their first child, while the other group of women were, on average, 33.8 years old when they had their first child. The distribution of the number of children also differs between the groups, where there is a significantly higher share among those who entered selfemployment before childbirth who did not have any children in 2013. The youngest women were 38 years old this year, so some will probably have children in the future. The share with one child is fairly similar, but a much higher proportion of women who entered selfemployment after childbirth have two, three, or more than three children. This is consistent with the idea that women who start a business before becoming mothers postpone the birth of their first child and, hence, will not have "time" to have as many children as women giving birth to their first child earlier.

The data cover a period of 19 years, which is a fairly long time. Therefore, it is interesting to look at the time span between self-employment entry and first child birth. If a woman has a child first, the average time until self-employment entry is 6.5 years. For women who became self-employed first, the average time until first child birth is 4.4 years.

Another set of variables included in the regressions and measured the same year as the outcomes are all characteristics of the firm: industry (11 categories), corporate form, and total time in self-employment. Selfemployed women, independent of group, are concentrated in a few industries: retailing, hotels and restaurants, business services, and cultural and personal services.

\section{Self-employment entry}

Before we turn to the results on self-employment performance, we look at the results for the self-employment entry equation. Among those in the sample who enter self-employment at some point during the observation period, approximately $32.4 \%$ enter self-employment when they do not have children, and $67.6 \%$ enter selfemployment after childbirth. It is hence much more common to become self-employed after having had a child. There are several explanations for this pattern. First, as is argued in several previous papers, the demand for being self-employed might increase when there are children in the household. Second, already having had a child, or possibly all children one plans to have, would mean that one no longer has to worry about how parental leave benefits would depend on selfemployment incomes. Third, women who have aspirations to become self-employed might also choose to postpone self-employment entry due to the fact that it might be difficult to combine business ownership and take care of a newborn child. If the mother wants to be on leave full-time from work just after the child is born, she might choose not to be self-employed during this period. This factor might also go in the other direction. Most wage-earning mothers in Sweden take a fairly long parental leave, around 1 year, and few combine parental leave with market work. If one, however, has a preference for a shorter period of parental leave or for combining parental leave and market work in a more flexible way, this would be more easily accomplished if one is self-employed than if one is organizationally employed. A previous Swedish study finds that self-employed women, on average, taker fewer days of parental leave than female wage-earners (Anxo and Ericson 2015). They suggest that this is explained by a portion of women with high performance-related income choosing self-employment over wage-employment.

To look at the impact of having children in period $t-1$ on the hazard rate into self-employment and to account for the impact of other covariates on selfemployment entry, we estimate Cox proportional hazard models. The sample is right-censored with respect to childbirth, meaning that some women in the sample had not had a child by 2013 , but it is possible that they will have. The model we estimate is

$$
h_{i}(t)=\exp \left(\beta \operatorname{Child}_{t-1}+\delta X_{t}+\gamma X_{t-1}\right) h_{0}(t)
$$

Here, covariates are measured the same year as selfemployment entry (marital status (married/single/other), education (seven categories), region of birth, county of residence), while labor market status 1 year prior to selfemployment entry (wage-earner, in education, unemployed, parental leave, and other) is measured at time $t-1$.

The result of this model is presented in Table 2. Consistent with previous research, we find a positive correlation between having a young child in period $t-1$ and the hazard rate into self-employment. In the simplest specification of the model without any controls, the hazard rate into self-employment is $10.1 \%$ higher if there were young children living in the household in 
Table 2 Hazard rate of self-employment entry in 1995-2013 of women born in 1970-1975

\begin{tabular}{|c|c|c|c|c|c|c|c|}
\hline & \multicolumn{7}{|c|}{ Self-employment entry in period $t$} \\
\hline & $\mathrm{I}$ & II & III & IV & $\mathrm{V}$ & VI & VII \\
\hline Young children in $t-1$ & $\begin{array}{l}1.100 * * * \\
(0.014)\end{array}$ & $\begin{array}{l}1.087 * * * \\
(0.014)\end{array}$ & $\begin{array}{l}1.087 * * * \\
(0.014)\end{array}$ & $\begin{array}{l}1.082 * * * \\
(0.014)\end{array}$ & $\begin{array}{l}1.066 * * * \\
(0.014)\end{array}$ & $\begin{array}{l}1.033 * * \\
(0.014)\end{array}$ & $\begin{array}{l}1.032 * * \\
(0.015)\end{array}$ \\
\hline Age, age squared & & $\mathrm{x}$ & $\mathrm{x}$ & $\mathrm{x}$ & $\mathrm{x}$ & $\mathrm{x}$ & $\mathrm{x}$ \\
\hline Region of birth & & & $\mathrm{x}$ & $\mathrm{x}$ & $\mathrm{x}$ & $\mathrm{x}$ & $\mathrm{x}$ \\
\hline County & & & & $\mathrm{x}$ & $\mathrm{x}$ & $\mathrm{x}$ & $\mathrm{x}$ \\
\hline Education & & & & & $\mathrm{x}$ & $\mathrm{x}$ & $\mathrm{x}$ \\
\hline Marital status & & & & & & $\mathrm{x}$ & $\mathrm{x}$ \\
\hline $\begin{array}{l}\text { Labor market } \\
\text { status } t-1\end{array}$ & & & & & & & $\mathrm{x}$ \\
\hline Industry $t-1$ & & & & & & & $\mathrm{x}$ \\
\hline Unemployment $t-1$ & & & & & & & $\mathrm{x}$ \\
\hline Observations & 254,961 & & & & & & \\
\hline Individuals & 25,977 & & & & & & \\
\hline
\end{tabular}

Standard error rates in parentheses

$* p<0.1 ; * * p<0.05 ; * * * p<0.01$

period $t-1$. When covariates are added a few at a time, the hazard rate decreases but remains above one and is significant. In the full model, the results show that the hazard rate into self-employment is $3.2 \%$ higher for women with young children. This means that when controlling for age and other cofounding variables, we find that it is more common to enter self-employment after childbirth than before.

In addition to estimating the impact of having young children in period $t-1$ as compared to not having young children, we also estimate the impact of the number of children in period $t-1$ on self-employment entry in period $t$ (see Table 3 ). The same specifications as before are estimated. Until the sixth specification, we see that having up to four children in the household is positively correlated with self-employment entry compared to having no children in the household. It is also interesting to note that the hazard rates are increasing in the number of children. However, when we control for marital status, we see that the hazard rate for having one child, as compared to have no children, becomes insignificant, while the hazard rate into self-employment of having two or three children is still positive and significant. These results indicate that it is not the change from having no child to having one child, i.e., becoming a parent, that is most important for the self-employment decision. Rather, it is an increase in the number of children, from one to two or from two to three, that has the largest impact on self-employment entry. This could mean that with a larger family, household responsibilities increase and so does the demand for flexible scheduling and self-employment. But it could also be an indication that women with two or three children have reached their complete fertility levels and do not plan to have more children. Becoming self-employed at this phase in the life cycle would then mean that one does not have to worry about how self-employment would impact pre-birth earnings and parental leave benefits. Women who are not planning to have more children would, in addition, not need to worry about what would have happened to the firm if they had been on parental leave.

\section{Self-employment outcomes}

Our initial hypothesis was that women who become self-employed after childbirth, i.e., those who become self-employed while being a mother of a young child, will not perform as well as women who are childless when they become self-employed. Women who do not have children can potentially spend more time on their business during the start-up phase, something that can be important for the success of the firm. Previous 
Table 3 Hazard rate of self-employment entry in 1995-2013 of women born in 1970-1975

\begin{tabular}{|c|c|c|c|c|c|c|c|}
\hline & \multicolumn{7}{|c|}{ Self-employment entry in period $t$} \\
\hline & I & II & III & IV & $\mathrm{V}$ & VI & VII \\
\hline \multicolumn{8}{|l|}{ Number of children in $t-1$} \\
\hline 0 & Reference & & & & & & \\
\hline \multirow[t]{2}{*}{1} & $1.071 * * *$ & $1.063 * * *$ & $1.061 * * *$ & $1.057 * * *$ & $1.043 * * *$ & 1.021 & 1.013 \\
\hline & $(0.017)$ & $(0.017)$ & $(0.017)$ & $(0.017)$ & $(0.017)$ & $(0.017)$ & $(0.018)$ \\
\hline \multirow[t]{2}{*}{2} & $1.112 * * *$ & $1.099 * * *$ & $1.098 * * *$ & $1.092 * * *$ & $1.072 * * *$ & $1.033^{*}$ & $1.043 * *$ \\
\hline & $(0.017)$ & $(0.017)$ & $(0.017)$ & $(0.017)$ & $(0.017)$ & $(0.017)$ & $(0.019)$ \\
\hline \multirow[t]{2}{*}{3} & $1.151^{* * *}$ & $1.138 * * *$ & $1.137 * * *$ & $1.129 * * *$ & $1.108 * * *$ & $1.060 * *$ & $1.050^{*}$ \\
\hline & $(0.027)$ & $(0.027)$ & $(0.027)$ & $(0.027)$ & $(0.026)$ & $(0.026)$ & $(0.028)$ \\
\hline \multirow[t]{2}{*}{4} & $1.156^{* * *}$ & $1.144 * * *$ & $1.143 * * *$ & $1.131 * *$ & $1.095^{*}$ & 1.044 & 0.984 \\
\hline & $(0.059)$ & $(0.059)$ & $(0.059)$ & $(0.058)$ & $(0.057)$ & $(0.055)$ & $(0.056)$ \\
\hline \multirow[t]{2}{*}{ More than 4} & 1.144 & 1.133 & 1.116 & 1.101 & 1.038 & 0.991 & 0.898 \\
\hline & $(0.169)$ & $(0.167)$ & $(0.168)$ & $(0.166)$ & $(0.159)$ & $(0.152)$ & $(0.148)$ \\
\hline Age, age squared & & $\mathrm{x}$ & $\mathrm{x}$ & $\mathrm{x}$ & $\mathrm{x}$ & $\mathrm{x}$ & $\mathrm{x}$ \\
\hline Region of birth & & & $\mathrm{x}$ & $\mathrm{x}$ & $\mathrm{x}$ & $\mathrm{x}$ & $\mathrm{x}$ \\
\hline County & & & & $\mathrm{x}$ & $\mathrm{x}$ & $\mathrm{x}$ & $\mathrm{x}$ \\
\hline Education & & & & & $\mathrm{x}$ & $\mathrm{x}$ & $\mathrm{x}$ \\
\hline Marital status & & & & & & $\mathrm{x}$ & $\mathrm{x}$ \\
\hline Labor market status $t-1$ & & & & & & & $\mathrm{x}$ \\
\hline Industry $t-1$ & & & & & & & $\mathrm{x}$ \\
\hline Unemployment $t-1$ & & & & & & & $\mathrm{x}$ \\
\hline Observations & 254,961 & & & & & & \\
\hline Individuals & 25,977 & & & & & & \\
\hline
\end{tabular}

Note: See Table 2

research also points towards differences in performance depending on the motives for becoming self-employed.

The results presented below indicate that our initial hypothesis is somewhat misleading. When controlling for a large set of background characteristics, women who start their business after having a child are in several respects more successful than women who start their business when not having children. In the concluding section, we provide some explanations for why this is the case. In Tables 4, 5, 6, 7, 8, and 9, we present the results from a number of regressions where we estimate the impact of entering self-employment after childbirth on (1) self-employment earnings, (2) the probability of belonging to the top 10 percentile in the self-employment earnings distribution, (3) net revenues in the firm, (4) the probability of having an incorporated firm, (5) number of employees, and (6) the probability of exiting self-employment. For each outcome, we estimate six different specifications of the model and include different sets of covariates to investigate the impact on the estimate of having a child when entering self-employment.

In the regressions, we use information on all years in which an individual is self-employed during our observation period of 1996-2013. Depending on the duration of self-employment and on the number of selfemployment spells, individuals will appear a different number of times. In all regressions, we include a control for the total number of years in self-employment and year. Standard errors are robust and clustered at the individual level.

Self-employment earnings are measured in logs; hence, we exclude those with negative incomes from self-employment. It is not evident that corporate form is a measure of success. However, up until the beginning of 2010 , there was a requirement of a capital investment 
Table 4 Self-employment earnings 1996-2013

\begin{tabular}{|c|c|c|c|c|c|c|}
\hline \multirow[t]{2}{*}{ Variables } & \multicolumn{6}{|c|}{ Self-employment earnings } \\
\hline & (1) & $(2)$ & (3) & (4) & $(5)$ & (6) \\
\hline Child at start & $\begin{array}{l}-0.102^{* * *} \\
(0.015)\end{array}$ & $\begin{array}{l}-0.069 * * * \\
(0.013)\end{array}$ & $\begin{array}{l}-0.060 \text { *** } \\
(0.014)\end{array}$ & $\begin{array}{l}0.135 * * * \\
(0.018)\end{array}$ & $\begin{array}{l}0.167 * * * \\
(0.018)\end{array}$ & $\begin{array}{l}0.235 * * * \\
(0.017)\end{array}$ \\
\hline Year dummies & $\mathrm{x}$ & $\mathrm{x}$ & $\mathrm{x}$ & $\mathrm{x}$ & $\mathrm{x}$ & $\mathrm{x}$ \\
\hline Years in self-emp. & & $\mathrm{x}$ & $\mathrm{x}$ & $\mathrm{x}$ & $\mathrm{x}$ & $\mathrm{x}$ \\
\hline Incorporated firm & & $\mathrm{x}$ & $\mathrm{x}$ & $\mathrm{x}$ & $\mathrm{x}$ & $\mathrm{x}$ \\
\hline Age, age squared at start & & & $\mathrm{x}$ & $\mathrm{x}$ & $\mathrm{x}$ & $\mathrm{x}$ \\
\hline Young children (yes/no) & & & & $\begin{array}{l}-0.169 * * * \\
(0.017)\end{array}$ & $\begin{array}{l}-0.194 * * * \\
(0.017)\end{array}$ & $\begin{array}{l}-0.220 * * * \\
(0.016)\end{array}$ \\
\hline Total number of children & & & & $\begin{array}{l}-0.075 * * * \\
(0.010)\end{array}$ & $\begin{array}{l}-0.064 * * * \\
(0.010)\end{array}$ & $\begin{array}{l}-0.049 * * * \\
(0.009)\end{array}$ \\
\hline Marital status at start & & & & $\mathrm{x}$ & $\mathrm{x}$ & $\mathrm{x}$ \\
\hline Education & & & & & $\mathrm{x}$ & $\mathrm{x}$ \\
\hline County & & & & & $\mathrm{x}$ & $\mathrm{x}$ \\
\hline Region of birth & & & & & $\mathrm{x}$ & $\mathrm{x}$ \\
\hline Industry & & & & & & $\mathrm{x}$ \\
\hline Labor market status $t-1$ & & & & & & $\mathrm{x}$ \\
\hline Earnings $t-1$ & & & & & & $\mathrm{x}$ \\
\hline Unemployment & & & & & & $\mathrm{x}$ \\
\hline Observations & 102,521 & 102,521 & 102,521 & 102,521 & 102,521 & 102,521 \\
\hline$R^{2}$ & 0.061 & 0.212 & 0.212 & 0.220 & 0.230 & 0.287 \\
\hline
\end{tabular}

Robust standard errors are in parentheses. Standard errors clustered at the individual level

$* p<0.1 ; * * p<0.05 ; * * * p<0.01$

${ }^{\text {a }}$ All incomes are expressed in 2013 prices

${ }^{\mathrm{b}}$ The exchange rate in 2013 was 10 SEK $=1.15$ Euro

of 100,000 SEK (approx. 10,000 euro) to start an incorporated firm. On April 1, 2010, this limit was reduced to 50,000 SEK (approx. 5000 euro). In our sample, approximately $27 \%$ started an incorporated firm; hence, it is more common to start an unincorporated firm. The size of the firm measured in terms of number of employees is often used as a measure of self-employment performance. ${ }^{12}$ The distribution of this variable is skewed, with approximately $49 \%$ of the self-employed having no employees. Therefore, we use a Tobit model in the regression analysis. Another measure of the

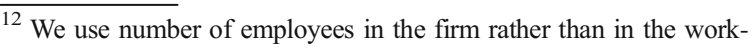
place. A larger firm can have many workplaces, but for small businesses often run by a self-employed person, firm and workplace coincide. The analysis was also performed using number of employees in the workplace, yielding the same result.
}

economy of the firm is the net revenues. This is also measured in logs, and hence, those with negative net revenues are excluded.

The last measure of self-employment success is the probability of exiting self-employment. The specification of this model differs slightly from the other outcomes, since we need to condition it on whether an individual is self-employed in period $t-1$. All covariates are also measured in period $t-1$. Exit is defined as a dummy variable equal to one if someone was self-employed in period $t-1$ but was no longer self-employed in period $t$ and zero if someone was self-employed in period $t-1$ and continued to be self-employed in period $t$.

The results for the different measures of selfemployment success are somewhat mixed. For selfemployment earnings, the probability of being a top income earner and net revenues, we find that women who 
Table 5 Probability of belonging to the top income percentile

\begin{tabular}{|c|c|c|c|c|c|c|}
\hline \multirow[t]{2}{*}{ Variables } & \multicolumn{6}{|c|}{$\operatorname{Pr}$ (top income percentile) } \\
\hline & (1) & (2) & (3) & (4) & $(5)$ & (6) \\
\hline \multirow[t]{2}{*}{ Child at start } & 0.005 & $-0.007 * *$ & $-0.015 * * *$ & 0.006 & $0.023 * * *$ & $0.047 * * *$ \\
\hline & $(0.004)$ & $(0.004)$ & $(0.004)$ & $(0.005)$ & $(0.005)$ & $(0.005)$ \\
\hline Year dummies & $\mathrm{x}$ & $\mathrm{x}$ & $\mathrm{x}$ & $\mathrm{x}$ & $\mathrm{x}$ & $\mathrm{x}$ \\
\hline Years in self-emp. & & $\mathrm{x}$ & $\mathrm{x}$ & $\mathrm{x}$ & $\mathrm{x}$ & $\mathrm{x}$ \\
\hline Incorporated firm & & $\mathrm{x}$ & $\mathrm{x}$ & $\mathrm{x}$ & $\mathrm{x}$ & $\mathrm{x}$ \\
\hline Age, age squared at start & & & $\mathrm{x}$ & $\mathrm{x}$ & $\mathrm{x}$ & $\mathrm{x}$ \\
\hline \multirow[t]{2}{*}{ Young children (yes/no) } & & & & $-0.012 * * *$ & $-0.023 * * *$ & $-0.028 * * *$ \\
\hline & & & & $(0.004)$ & $(0.004)$ & $(0.004)$ \\
\hline \multirow[t]{2}{*}{ Total number of children } & & & & $-0.014 * * *$ & $-0.009 * * *$ & $-0.005 * * *$ \\
\hline & & & & $(0.002)$ & $(0.002)$ & $(0.002)$ \\
\hline Marital status at start & & & & $\mathrm{x}$ & $\mathrm{x}$ & $\mathrm{x}$ \\
\hline Education & & & & & $\mathrm{x}$ & $\mathrm{x}$ \\
\hline County & & & & & $\mathrm{x}$ & $\mathrm{x}$ \\
\hline Region of birth & & & & & $\mathrm{x}$ & $\mathrm{x}$ \\
\hline Industry & & & & & & $\mathrm{x}$ \\
\hline Labor market status $t-1$ & & & & & & $\mathrm{x}$ \\
\hline Earnings $t-1$ & & & & & & $\mathrm{x}$ \\
\hline Unemployment & & & & & & $\mathrm{x}$ \\
\hline Observations & 102,521 & 102,521 & 102,521 & 102,521 & 102,521 & 102,521 \\
\hline$R^{2}$ & 0.034 & 0.101 & 0.102 & 0.104 & 0.132 & 0.214 \\
\hline
\end{tabular}

Note: See Table 4

entered self-employment after childbirth perform better compared to women who entered self-employment before childbirth. In the first earnings regression, which does not include any covariates, we find that self-employed who had a child when entering self-employment on average have lower incomes. The estimate, however, changes sign when controls for children and marital status are included. Having young children is correlated with lower earnings, and since those who were childless when entering selfemployment postpone childbearing, this means that they have younger children, on average, when we measure outcomes. In the final regression, where the full set of covariates is included, women who entered selfemployment after childbirth have, on average, approximately $23 \%$ higher income. For the probability of belonging to the top 10 percentiles in income, we basically find the same pattern. In the first three specifications of the model, it appears that women entering self-employment after childbirth have a significantly lower chance of reaching the highest income percentile, but when controls for children and marital status are included, they have a significantly higher probability.

For net revenues, we find a positive estimate in all specifications. It is large in the first specification but decreases in size as more controls are added. In the last specification, however, it is of the same size as in the first specification. It should be noted that the $R^{2}$ value is large already in the second specification, when controls for corporate form are included; hence, this appears to explain a large part of the variation in revenues. If the full specification of the model is estimated only for those with unincorporated firms, the estimate for "child at start" is very similar to the corresponding estimate for the whole model ( $\beta=0.253$ ), while the $R^{2}$ value is only 0.1618 .

It can be questioned whether corporate firm is actually a measure of performance, but having an incorporated firm is positively correlated with success in general and is included as a control variable in all the other regressions. In most cases, it is a very strong predictor of selfemployment success (Appendix 1 Table 10). We find that 
Table 6 (ln)Net revenues in the firm, 1995-2013

\begin{tabular}{|c|c|c|c|c|c|c|}
\hline \multirow[t]{2}{*}{ Variables } & \multicolumn{6}{|c|}{ (ln)Net revenues } \\
\hline & (1) & $(2)$ & (3) & (4) & $(5)$ & (6) \\
\hline Child at start & $\begin{array}{l}0.233 * * * \\
(0.029)\end{array}$ & $\begin{array}{l}0.078 * * * \\
(0.020)\end{array}$ & $\begin{array}{l}0.142 * * * \\
(0.022)\end{array}$ & $\begin{array}{l}0.192 * * * \\
(0.028)\end{array}$ & $\begin{array}{l}0.167 * * * \\
(0.028)\end{array}$ & $\begin{array}{l}0.253 * * * \\
(0.027)\end{array}$ \\
\hline Year dummies & $\mathrm{x}$ & $\mathrm{x}$ & $\mathrm{x}$ & $\mathrm{x}$ & $\mathrm{x}$ & $\mathrm{x}$ \\
\hline Years in self-emp. & & $\mathrm{x}$ & $\mathrm{x}$ & $\mathrm{x}$ & $\mathrm{x}$ & $\mathrm{x}$ \\
\hline Incorporated firm & & $\mathrm{x}$ & $\mathrm{x}$ & $\mathrm{x}$ & $\mathrm{x}$ & $\mathrm{x}$ \\
\hline Age, age squared at start & & & $\mathrm{x}$ & $\mathrm{x}$ & $\mathrm{x}$ & $\mathrm{x}$ \\
\hline Young children (yes/no) & & & & $\begin{array}{l}-0.199 * * * \\
(0.024)\end{array}$ & $\begin{array}{l}-0.178 * * * \\
(0.024)\end{array}$ & $\begin{array}{l}-0.182 * * * \\
(0.022)\end{array}$ \\
\hline Total number of children & & & & $\begin{array}{l}0.032 * * \\
(0.015)\end{array}$ & $\begin{array}{l}0.024 * \\
(0.015)\end{array}$ & $\begin{array}{l}0.016 \\
(0.014)\end{array}$ \\
\hline Marital status at start & & & & $\mathrm{x}$ & $\mathrm{x}$ & $\mathrm{x}$ \\
\hline Education & & & & & $\mathrm{x}$ & $\mathrm{x}$ \\
\hline County & & & & & $\mathrm{x}$ & $\mathrm{x}$ \\
\hline Region of birth & & & & & $\mathrm{x}$ & $\mathrm{x}$ \\
\hline Industry & & & & & & $\mathrm{x}$ \\
\hline Labor market status $t-1$ & & & & & & $\mathrm{x}$ \\
\hline Earnings $t-1$ & & & & & & $\mathrm{x}$ \\
\hline Observations & 93,059 & 93,059 & 93,059 & 93,059 & 93,059 & 93,059 \\
\hline$R^{2}$ & 0.017 & 0.463 & 0.466 & 0.467 & 0.471 & 0.521 \\
\hline
\end{tabular}

Note: See Table 4

women who entered self-employment after childbirth are more likely to have a firm registered as an incorporated firm. The estimates are positive and significant in all specifications, but they decrease in size as more controls are included.

Table 8 presents the results for the number of employees. The distribution of the number of this variable is skewed, with nearly $50 \%$ of the selfemployed having no employees. Following Burke et al. (2002), we investigate the difference in firm size between the groups and the impact of other covariates by estimating a Tobit model. The same specifications as before are estimated. In the first three specifications, we find a positive correlation between having entered self-employment after childbirth and the number of employees. The interpretation of the estimate in the third specification is that the expected number of employees is 28.6 persons higher in firms started by women who had children. In the fourth and fifth specifications, where controls for having young children, the total number of children in the household and marital status are included, the estimate is no longer significantly different from zero. However, in the last specification, the estimate becomes significantly different from zero again and indicates that women who had a child at the start have, on average, approximately 26 more employees in their firms. In the last specification, we have added four additional covariates: industry, labor market status prior to self-employment entry, earnings prior to self-employment entry, and the regional unemployment rate. Adding these variables one at the time, we see that it is the inclusion of earnings the year before entering self-employment that leads to a significant estimate of child at start. This is positively correlated with the number of employees and could be an indication of financial resources when starting the firm.

The last measure of performance is exits from self-employment. The results from the same specifications as before are presented in Table 9. The presence of young children seems to play an important role for the exit rate as well. When this is 
Table 7 Probability of having an incorporated firm. Linear probability model

\begin{tabular}{|c|c|c|c|c|c|c|}
\hline \multirow[t]{2}{*}{ Variables } & \multicolumn{6}{|c|}{$\operatorname{Pr}($ incorporated firm $)$} \\
\hline & (1) & $(2)$ & (3) & (4) & $(5)$ & (6) \\
\hline \multirow[t]{2}{*}{ Child at start } & $0.069 * * *$ & $0.066^{* * *}$ & $0.064 * * *$ & $0.033 * * *$ & $0.035 * * *$ & $0.062 * * *$ \\
\hline & $(0.007)$ & $(0.007)$ & $(0.007)$ & $(0.010)$ & $(0.010)$ & $(0.008)$ \\
\hline Year dummies & $\mathrm{x}$ & $\mathrm{x}$ & $\mathrm{x}$ & $\mathrm{x}$ & $\mathrm{x}$ & $\mathrm{x}$ \\
\hline Years in self-emp. & & $\mathrm{x}$ & $\mathrm{x}$ & $\mathrm{x}$ & $\mathrm{x}$ & $\mathrm{x}$ \\
\hline Incorporated firm & & $\mathrm{x}$ & $\mathrm{x}$ & $\mathrm{x}$ & $\mathrm{x}$ & $\mathrm{x}$ \\
\hline Age, age squared at start & & & $\mathrm{x}$ & $\mathrm{x}$ & $\mathrm{x}$ & $\mathrm{x}$ \\
\hline \multirow[t]{2}{*}{ Young children (yes/no) } & & & & $0.043 * * *$ & $0.041 * * *$ & $0.017 * * *$ \\
\hline & & & & $(0.008)$ & $(0.008)$ & $(0.006)$ \\
\hline \multirow[t]{2}{*}{ Total number of children } & & & & $-0.015 * * *$ & $-0.016^{* * *}$ & -0.004 \\
\hline & & & & $(0.004)$ & $(0.004)$ & $(0.004)$ \\
\hline Marital status at start & & & & $\mathrm{x}$ & $\mathrm{x}$ & $\mathrm{x}$ \\
\hline Education & & & & & $\mathrm{x}$ & $\mathrm{x}$ \\
\hline County & & & & & $\mathrm{x}$ & $\mathrm{x}$ \\
\hline Region of birth & & & & & $\mathrm{x}$ & $\mathrm{x}$ \\
\hline Industry & & & & & & $\mathrm{x}$ \\
\hline Labor market status $t-1$ & & & & & & $\mathrm{x}$ \\
\hline Earnings $t-1$ & & & & & & $\mathrm{x}$ \\
\hline Observations & 118,629 & 118,629 & 118,629 & 118,629 & 118,629 & 118,629 \\
\hline$R^{2}$ & 0.030 & 0.030 & 0.032 & 0.037 & 0.044 & 0.278 \\
\hline
\end{tabular}

Note: See Table 4

not controlled for in the first three specifications, we find that women who entered self-employment after childbirth are significantly more likely to exit self-employment. In the fourth specification, when we include controls for the presence of children and marital status 1 year prior to self-employment exit, the estimate changes sign and is no longer significantly different from zero. We also find that that having young children in itself increases the probability of exiting self-employment. This is consistent with the results found in Lin et al. (2000). Hence, the presence of young children appears to be positively correlated with both entries into and exits from self-employment.

Comparing all outcomes, we see that the results are somewhat mixed. One the one hand, we find that women, who already had children when they became selfemployed have higher incomes, are more likely to belong to the top income percentile and have higher revenues. On the other hand, we find no difference in the exit rate. For firm size, the results from the Tobit model suggest that women who had a child at start employ, on average, more employees. ${ }^{13}$ There are, hence, no indications of that women who were mothers when entering self-employment perform worse compared to women who entered self-employment while being childless.

It is interesting to note that the outcomes for which we find a positive effect of motherhood at selfemployment entry are short-term measures of selfemployment performance. There could potentially be large variations in income and revenues over time, and income and revenues could be affected by fertility rates during this particular year. The inclusion of controls for the presence of young children and the total number of children in the same years as when the outcomes are measured has a large impact on the estimated difference between women who enter self-employment before and after childbirth. More long-term measures of selfemployment performance, such as the exit rate, might

\footnotetext{
${ }^{13}$ We have also estimated linear probability models for the probability of having employees or not, i.e., measuring firm size with a dummy variable. The results from these models indicate that there is no difference between the groups with respect to the probability of having employees. The results are available from the author upon request.
} 
depend less on the activities or the family situation of the self-employed herself during a single year.

\subsection{Impact of other covariates on self-employment performance}

In Appendix 1 Table 10, we present the results for all control variables from the final specification of the model, where all covariates are included at the same time. ${ }^{14}$ Duration in self-employment, having an incorporated firm, being married, living in the area around the capital, and earnings prior to self-employment are positively correlated with all measures of success. The finding that time spent in self-employment decreases the risk of exiting self-employment is consistent with previous findings for Canada reported in Lin et al. (2000).

Several of the other covariates affect different outcomes differently. Previous studies have studied in detail the impact of education on self-employment success. We find that education, to a high degree, is uncorrelated with self-employment performance. Exceptions are the number of employees and revenues, where we find a negative correlation between education and the outcomes. This supports the hypothesis that formal education is not very important for entrepreneurial success, but it contradicts the empirical findings in, for example, Marshall and Flaig (2014), who find that education matters for self-employment performance among women in the USA. In an alternative specification of the model, we include a more aggregated measure of education that includes primary school, upper secondary school, university (including post-graduate studies), and missing information. ${ }^{15}$ Upper secondary school is chosen to be the reference group. The results indicate that self-employed women with at least some university education are more likely to become a top income entrepreneur but less likely to have an incorporated firm. They also have fewer employees, lower revenues, and are more likely to exit self-employment. Hence, this specification does not give any clear indications that self-employed with higher education perform better than those with lower education. It is, however, important to

\footnotetext{
${ }^{14}$ The number of observations differs depending on outcome. This is due to zero or negative earnings in some years and/or negative revenues in the firm.

15 The specifications of the models using these educational categories are not presented in the paper but are available from the author upon request.
}

keep in mind that we study a sample of fairly young women who are between 38 and 43 years of age during the last year included in the analysis. It is possible that the impact of education on self-employment performance is different among men or among older women.

Birth region is also not a very important predictor of self-employment success. The results indicate a difference between women born in Sweden and women born in Asia, but the results go in different directions. Immigrant women appear to have lower incomes and a lower probability of having an incorporated firm but are more likely to belong to the top income percentile, have more employees and have higher revenues in their firms. There is no difference in the exit rate.

For industry, we find that women in "personal and cultural services" are those with the most adverse outcomes compared to women in, for example, "retailing and communications" or "financial and business services." This is an industry that can be characterized as having low entry barriers, where low financial investments are usually needed to start a business.

Earlier studies have found that previous labor market experience is important for outcomes. We find somewhat mixed evidence on this. The results do not unanimously indicate that having entered from unemployment is correlated with worse outcomes than having entered from wage-employment. Also, being in the residual category "other" is correlated with a higher probability of being in the top income percentile, having more employees and having higher revenues.

Our measure of macroeconomic conditions, i.e., regional unemployment, is insignificant for all outcomes except the probability of being a top income earner, and hence, it seems to be of minor importance, given that we control for a large set of individual and business characteristics.

Corporate form, indicated by the dummy variable "incorporated firm," indicates for all outcomes that having an incorporated firm is correlated with better outcomes. Corporate form is, however, not exogenous, but the choice of corporate firm is likely to be correlated with (expected) performance. As a sensitivity analysis, we re-estimate all models excluding all self-employed with incorporated firms. ${ }^{16}$ The results for our main variables of

\footnotetext{
$\overline{16}$ This leads to a drop in the sample size by approximately one third. The results are not presented here but are available from the author upon request.
} 
Table 8 Number of employees in the firm. Tobit model

\begin{tabular}{|c|c|c|c|c|c|c|}
\hline \multirow[b]{2}{*}{ Variables } & \multicolumn{6}{|c|}{ Number of employees } \\
\hline & (1) & (2) & (3) & (4) & $(5)$ & (6) \\
\hline Child at start & $\begin{array}{l}76.887 * * * \\
(13.565)\end{array}$ & $\begin{array}{l}29.147 * * * \\
(10.606)\end{array}$ & $\begin{array}{l}28.569 * * * \\
(10.392)\end{array}$ & $\begin{array}{l}18.760 \\
(11.920)\end{array}$ & $\begin{array}{l}15.409 \\
(12.138)\end{array}$ & $\begin{array}{l}25.798 * * \\
(12.924)\end{array}$ \\
\hline $\begin{array}{l}\text { Year dummies } \\
\text { Years in self-emp. } \\
\text { Incorporated firm } \\
\text { Age, age squared at start }\end{array}$ & & & & & & \\
\hline Young children (yes/no) & & & & $\begin{array}{l}-3.485 \\
(8.668)\end{array}$ & $\begin{array}{l}-0.344 \\
(8.754)\end{array}$ & $\begin{array}{l}4.638 \\
(8.631)\end{array}$ \\
\hline Total number of children & & & & $\begin{array}{l}10.192 \\
(7.116)\end{array}$ & $\begin{array}{l}8.951 \\
(7.164)\end{array}$ & $\begin{array}{l}5.762 \\
(7.123)\end{array}$ \\
\hline \multicolumn{7}{|l|}{ Marital status at start } \\
\hline \multicolumn{7}{|l|}{ Education } \\
\hline \multicolumn{7}{|l|}{ County } \\
\hline \multicolumn{7}{|l|}{ Region of birth } \\
\hline \multicolumn{7}{|l|}{ Industry } \\
\hline \multicolumn{7}{|l|}{ Labor market status $t-1$} \\
\hline \multicolumn{7}{|l|}{ Earnings $t-1$} \\
\hline Observations & 94,838 & 94,838 & 94,838 & 94,838 & 94,838 & 94,838 \\
\hline Sigma & $\begin{array}{l}416.680 * * * \\
(50.336)\end{array}$ & $\begin{array}{l}405.678 * * * \\
(48.181)\end{array}$ & $\begin{array}{l}405.652 * * * \\
(48.165)\end{array}$ & $\begin{array}{l}405.452 * * * \\
(48.100)\end{array}$ & $\begin{array}{l}404.232 * * * \\
(47.533)\end{array}$ & $\begin{array}{l}396.586 \text { *** } \\
(44.890)\end{array}$ \\
\hline
\end{tabular}

Note: See Table 4

interest (having a child at start) are not affected by this exclusion in the earnings and revenue regressions. However, the results indicate no difference in firm size. We also find that among women with unincorporated firms, having had a child at the time of start is correlated with a higher exit rate. This is opposite to what we found using the full sample.

\section{Discussion}

Both labor force participation and fertility rates are high among Swedish women, and women participate in the labor force to a high extent also when the children are young. Even though there is publically provided high-quality child care that makes it possible for mothers, and fathers, with young children to participate in the labor market, having children still means a lot of work.
Anecdotal evidence indicates that it is not uncommon for women in fertile ages to leave a wage-earning job to become self-employed, not primarily because they aim at becoming successful entrepreneurs and earn a lot of money, but because self-employment offers a way of being able to have it all, a career and a family, without being pushed to the limit of one's capabilities.

Our initial hypothesis was that women who already had children when entering selfemployment perform less well compared to women who did not have children when becoming selfemployed. One reason to expect that women who are childless when becoming self-employed perform better is that they can potentially spend more time on market work compared to women who have children during the start-up phase of the firm.

Our results do not lend support to this hypothesis. We find that women who had a child at the time of self-employment entry have higher incomes and higher revenues and are employing 
Table 9 Exits from self-employment. Linear probability model

\begin{tabular}{|c|c|c|c|c|c|c|}
\hline & \multicolumn{6}{|c|}{ Exits from self-employment } \\
\hline & (1) & (2) & (3) & (4) & (5) & (6) \\
\hline Child at start & $\begin{array}{l}0.086 * * * \\
(0.003)\end{array}$ & $\begin{array}{l}0.011 * * * \\
(0.002)\end{array}$ & $\begin{array}{l}0.018 * * * \\
(0.003)\end{array}$ & $\begin{array}{l}0.003 \\
(0.003)\end{array}$ & $\begin{array}{l}0.004 \\
(0.003)\end{array}$ & $\begin{array}{l}-0.001 \\
(0.003)\end{array}$ \\
\hline Year dummies & $\mathrm{x}$ & $\mathrm{x}$ & $\mathrm{x}$ & $\mathrm{x}$ & $\mathrm{x}$ & $\mathrm{x}$ \\
\hline Years in self-emp. & & $\mathrm{x}$ & $\mathrm{x}$ & $\mathrm{x}$ & $\mathrm{x}$ & $\mathrm{x}$ \\
\hline Incorporated firm & & $\mathrm{x}$ & $\mathrm{x}$ & $\mathrm{x}$ & $\mathrm{x}$ & $\mathrm{x}$ \\
\hline Age, age squared at start & & & $\mathrm{x}$ & $\mathrm{x}$ & $\mathrm{x}$ & $\mathrm{x}$ \\
\hline $\begin{array}{l}\text { Young children } \\
\text { (yes/no) }\end{array}$ & & & & $\begin{array}{l}0.022 * * * \\
(0.004)\end{array}$ & $\begin{array}{l}0.021 * * * \\
(0.004)\end{array}$ & $\begin{array}{l}0.024 * * * \\
(0.004)\end{array}$ \\
\hline Total number of children & & & & $\begin{array}{l}0.002 \\
(0.002)\end{array}$ & $\begin{array}{l}0.003 \\
(0.002)\end{array}$ & $\begin{array}{l}0.001 \\
(0.002)\end{array}$ \\
\hline Marital status at start & & & & $\mathrm{x}$ & $\mathrm{x}$ & $\mathrm{x}$ \\
\hline Education & & & & & $\mathrm{x}$ & $\mathrm{x}$ \\
\hline County & & & & & $\mathrm{x}$ & $\mathrm{x}$ \\
\hline Region of birth & & & & & $\mathrm{x}$ & $\mathrm{x}$ \\
\hline Industry & & & & & & $\mathrm{x}$ \\
\hline Labor market status $t-2$ & & & & & & $\mathrm{x}$ \\
\hline Earnings $t-2$ & & & & & & \\
\hline Observations & 106,768 & 106,768 & 106,768 & 106,768 & 106,768 & 106,768 \\
\hline$R^{2}$ & 0.017 & 0.196 & 0.203 & 0.203 & 0.204 & 0.206 \\
\hline
\end{tabular}

Note: See Table 4

more people in their firms, while we find no difference in exit rate out from self-employment between the groups. The variables that seem to be most important to control for are the presence of young children and total number of children the same year as outcomes are measured. Having young children is generally negatively correlated with all outcomes, and women who start their firm before they have children are likely to postpone the birth of their first child and, hence, are more likely to have younger children when outcomes are measured.

In a sensitivity analysis, we separately looked at selfemployed women who had not yet had a child at the end of our observation period, but this group appears to be the least successful (results not shown). This leads us to the conclusion that female business owners who trade family formation and childbearing for a successful career are few. In our sample, many of the women who are successful as entrepreneurs started their firm while being a mother and while the children were young. If we look at some simple descriptive statistics for women who belong to the top income percentile in the most recent year in which we observe them in selfemployment and with positive incomes from self-employment, we see that nearly $75 \%$ of women in the top of the income distribution had children when they entered self-employment. At the bottom (P10) and at the median (P50), the share is almost $10 \%$ points lower. See Appendix 2 Table 11. A larger share of women at the top have two children, while a lower share have no young children in the household. Women at the bottom of the income distribution stand out in that a larger share have no children, but a larger share also have large families with four or more children. Part of the difference in fertility rates can be explained by differences in age, where both present age and age at the time of selfemployment entry is positively correlated with location in the income distribution.

What are possible explanations for these results? First, we observed that the majority of women who did not have children at self-employment entry postpone childbearing and have their children later. Mechanically, this means that this group of women, on average, has 
younger children when we measure self-employment outcomes, and we have seen that the presence of young children has a negative impact on self-employment performance. Second, becoming a mother in general can mean that one becomes more efficient at work, independently of whether one is a wage-earner or selfemployed. If this is the case, the estimated correlations can be interpreted as a causal effect of motherhood on self-employment performance. We do not suggest that this is the only interpretation of our results. Third, socalled mamatreneurs come up with better business ideas and, as a result, perform better. "Mamatreneurs" are defined as a group of self-employed women who, because of their motherhood, discover market opportunities that are related to children or motherhood itself. Fourth, there is a selection of more motivated and more ambitious women who manage to start a business when they have (young) children. If this is the case, it means that we have not estimated the causal effect.

An additional explanation can be borrowed from Lazear's theory that entrepreneurs are jacks-of-all trades (Lazear 2004). He argues that individuals with a more balanced set of skills are more likely to be self-employed. Becoming a parent means that one learns, for most adults, a totally new set of skills. Some are directly related to taking care of a child, but some are related to the organization of a family in general. It could be things such as having meals ready at a certain hour or having routines at bedtime and in the morning when the family needs to get ready for kindergarten, school, and work. Learning such skills could also be a factor that leads an individual to the decision of becoming self-employed, which might also have a positive impact on self-employment performance.

The entrepreneurship literature often makes a distinction between necessity- and opportunitydriven entrepreneurship. Previous literature has found differences in outcomes depending on type of entrepreneurship. However, in the present paper, it is difficult to arrive at a hypothesis about the correlation between type and having a child at the time of self-employment entry. It would be possible to find entrepreneurs of both types, necessity and opportunity, not only among women who enter self-employment when having children but also among women who do not have children when entering self-employment. In the regression analysis, we control for previous labor market status, which is most likely the information we have that would be our best proxy for whether entrepreneurship is necessity or opportunity driven. Labor market status prior to self-employment is similar between the groups, and the inclusion of this variable in the regressions has a rather small impact on our key variable of interest.

There is an outspoken goal to increase selfemployment among women. The primary reason is that female entrepreneurs, just as male entrepreneurs, are believed to contribute to economic growth and job creation. For some individuals, self-employment could also be a solution to a situation of economic inactivity or unemployment. At the same time, several studies indicate that women are less likely to choose self-employment for economic reasons and more likely to choose it for family-related reasons. In this paper, we compare the self-employment outcomes of two groups of women who started their business during different phases of their life cycles. Our results do not indicate that female self-employed who had young children at the time of self-employment entry perform less well than women who are childless when becoming self-employed. One interpretation of these results is that there does not need to be a contradiction between becoming self-employed when the children are young and being a successful entrepreneur.

In future studies, it would be very interesting to see whether similar results can be found in countries with another institutional setting, i.e., where labor force participation among mothers with young children is lower and where many women choose to leave a wage-earning job when the children are young. Also, as is indicated by the analysis of time-use data, self-employed women in Sweden spend as much, or more, time on market work than wage-earning women, while the opposite pattern has been found in many other countries. This could be an indication that Swedish mothers who choose selfemployment when the children are young have strong preferences for market work, which also might have an impact on subsequent self-employment success.

Acknowledgements The author wants to thank Kristina Nyström, Eskil Wadensjö, seminar participants at the Ratio Institute in Stockholm and two anonymous reviewers for comments on earlier version of the paper. The author also gratefully acknowledges financial support from the Swedish Research Council (VR). 


\section{Appendix 1}

Table 10 Self-employment outcomes - a summary of the results

\begin{tabular}{|c|c|c|c|c|c|c|}
\hline $\begin{array}{l}\text { Method } \\
\text { Outcome }\end{array}$ & $\begin{array}{l}\text { OLS } \\
\text { Ln(income) }\end{array}$ & $\begin{array}{l}\text { OLS } \\
\text { Top income } \\
\text { percentile }\end{array}$ & $\begin{array}{l}\text { OLS } \\
\text { Ln(revenue) }\end{array}$ & $\begin{array}{l}\text { OLS } \\
\text { Incorporated } \\
\text { firm }\end{array}$ & $\begin{array}{l}\text { Tobit } \\
\text { Number of } \\
\text { employees }\end{array}$ & $\begin{array}{l}\text { OLS } \\
\text { Exit }\end{array}$ \\
\hline Child at start & $\begin{array}{l}0.235 * * * \\
(0.017)\end{array}$ & $\begin{array}{l}0.047 * * * \\
(0.005)\end{array}$ & $\begin{array}{l}0.253 * * * \\
(0.027)\end{array}$ & $\begin{array}{l}0.062 * * * \\
(0.008)\end{array}$ & $\begin{array}{l}25.798 * * \\
(12.924)\end{array}$ & $\begin{array}{l}-0.001 \\
(0.003)\end{array}$ \\
\hline Years in self-employment & $\begin{array}{l}0.059 * * * \\
(0.001)\end{array}$ & $\begin{array}{l}0.004 * * * \\
(0.000)\end{array}$ & $\begin{array}{l}0.049 * * * \\
(0.002)\end{array}$ & $\begin{array}{l}0.002 * * * \\
(0.001)\end{array}$ & $\begin{array}{l}4.453 * * * \\
(1.193)\end{array}$ & $\begin{array}{l}-0.042 * * * \\
(0.000)\end{array}$ \\
\hline Age at start & $\begin{array}{l}-0.022 \\
(0.015)\end{array}$ & $\begin{array}{l}0.005 \\
(0.003)\end{array}$ & $\begin{array}{l}0.056 * * \\
(0.022)\end{array}$ & $\begin{array}{l}0.036 * * * \\
(0.007)\end{array}$ & $\begin{array}{l}0.805 \\
(8.836)\end{array}$ & $\begin{array}{l}-0.084 * * * \\
(0.003)\end{array}$ \\
\hline Age at start squared & $\begin{array}{l}-0.000 \\
(0.000)\end{array}$ & $\begin{array}{l}-0.000 * * * \\
(0.000)\end{array}$ & $\begin{array}{l}-0.001 * * * \\
(0.000)\end{array}$ & $\begin{array}{l}-0.001 * * * \\
(0.000)\end{array}$ & $\begin{array}{l}-0.086 \\
(0.136)\end{array}$ & $\begin{array}{l}0.001 * * * \\
(0.000)\end{array}$ \\
\hline Incorporated firm & $\begin{array}{l}0.715^{* * * *} \\
(0.012)\end{array}$ & $\begin{array}{l}0.105^{* * * *} \\
(0.004)\end{array}$ & $\begin{array}{l}2.162 * * * \\
(0.023)\end{array}$ & - & $\begin{array}{l}584.897 * * * \\
(70.935)\end{array}$ & $\begin{array}{l}-0.029 * * * \\
(0.003)\end{array}$ \\
\hline Young children & $\begin{array}{l}-0.220 * * * \\
(0.016)\end{array}$ & $\begin{array}{l}-0.028 * * * \\
(0.004)\end{array}$ & $\begin{array}{l}-0.182^{* * * *} \\
(0.022)\end{array}$ & $\begin{array}{l}0.017 * * \\
(0.006)\end{array}$ & $\begin{array}{l}4.638 \\
(8.631)\end{array}$ & $\begin{array}{l}0.024 * * * \\
(0.004)\end{array}$ \\
\hline $\begin{array}{l}\text { Total number of } \\
\text { children }\end{array}$ & $\begin{array}{l}-0.049 * * * \\
(0.009)\end{array}$ & $\begin{array}{l}-0.006^{* * * *} \\
(0.002)\end{array}$ & $\begin{array}{l}0.015 \\
(0.014)\end{array}$ & $\begin{array}{l}-0.004 \\
(0.004)\end{array}$ & $\begin{array}{l}5.762 \\
(7.123)\end{array}$ & $\begin{array}{l}0.001 \\
(0.002)\end{array}$ \\
\hline \multicolumn{7}{|l|}{ Marital status } \\
\hline Married & Reference & & & & & \\
\hline Single & $\begin{array}{l}-0.025^{*} \\
(0.013)\end{array}$ & $\begin{array}{l}-0.004 \\
(0.003)\end{array}$ & $\begin{array}{l}-0.045^{* *} \\
(0.021)\end{array}$ & $\begin{array}{l}-0.042^{* * *} \\
(0.006)\end{array}$ & $\begin{array}{l}-15.534 \\
(9.611)\end{array}$ & $\begin{array}{l}0.006 * * \\
(0.003)\end{array}$ \\
\hline Other & $\begin{array}{l}0.017 \\
(0.028)\end{array}$ & $\begin{array}{l}0.009 \\
(0.008)\end{array}$ & $\begin{array}{l}-0.013 \\
(0.041)\end{array}$ & $\begin{array}{l}-0.049 * * * \\
(0.012)\end{array}$ & $\begin{array}{l}30.068 \\
(22.919)\end{array}$ & $\begin{array}{l}0.014 * * \\
(0.006)\end{array}$ \\
\hline \multicolumn{7}{|l|}{ Education } \\
\hline Primary education ( $<9$ years $)$ & Reference & & & & & \\
\hline Primary education ( 9 years) & $\begin{array}{l}0.054 \\
(0.175)\end{array}$ & $\begin{array}{l}-0.032 \\
(0.022)\end{array}$ & $\begin{array}{l}-0.402 * * * \\
(0.145)\end{array}$ & $\begin{array}{l}0.041 \\
(0.048)\end{array}$ & $\begin{array}{l}-133.463 * * * \\
(39.947)\end{array}$ & $\begin{array}{l}0.013 \\
(0.026)\end{array}$ \\
\hline Upper secondary education ( $\leq 2$ years) & $\begin{array}{l}0.080 \\
(0.173)\end{array}$ & $\begin{array}{l}-0.028 \\
(0.022)\end{array}$ & $\begin{array}{l}-0.329 * * \\
(0.142)\end{array}$ & $\begin{array}{l}0.049 \\
(0.047)\end{array}$ & $\begin{array}{l}-136.620 * * * \\
(39.492)\end{array}$ & $\begin{array}{l}-0.005 \\
(0.026)\end{array}$ \\
\hline Upper secondary education (3 years) & $\begin{array}{l}0.109 \\
(0.173)\end{array}$ & $\begin{array}{l}-0.033 \\
(0.022)\end{array}$ & $\begin{array}{l}-0.430 * * * \\
(0.142)\end{array}$ & $\begin{array}{l}0.045 \\
(0.047)\end{array}$ & $\begin{array}{l}-167.822 * * * \\
(41.108)\end{array}$ & $\begin{array}{l}0.007 \\
(0.026)\end{array}$ \\
\hline University $<3$ years & $\begin{array}{l}0.048 \\
(0.174)\end{array}$ & $\begin{array}{l}-0.013 \\
(0.022)\end{array}$ & $\begin{array}{l}-0.505^{* * *} \\
(0.143)\end{array}$ & $\begin{array}{l}0.036 \\
(0.047)\end{array}$ & $\begin{array}{l}-185.944 * * * \\
(42.463)\end{array}$ & $\begin{array}{l}0.010 \\
(0.026)\end{array}$ \\
\hline University $\geq 3$ years & $\begin{array}{l}0.124 \\
(0.174)\end{array}$ & $\begin{array}{l}0.020 \\
(0.022)\end{array}$ & $\begin{array}{l}-0.542 * * * \\
(0.142)\end{array}$ & $\begin{array}{l}0.038 \\
(0.047)\end{array}$ & $\begin{array}{l}-151.522 * * * \\
(37.824)\end{array}$ & $\begin{array}{l}0.015 \\
(0.026)\end{array}$ \\
\hline Post-graduate studies & $\begin{array}{l}0.090 \\
(0.194)\end{array}$ & $\begin{array}{l}-0.015 \\
(0.032)\end{array}$ & $\begin{array}{l}-0.640 * * * \\
(0.192)\end{array}$ & $\begin{array}{l}0.017 \\
(0.060)\end{array}$ & $\begin{array}{l}-188.039 * * * \\
(60.845)\end{array}$ & $\begin{array}{l}0.068 * * \\
(0.034)\end{array}$ \\
\hline Unknown & $\begin{array}{l}0.140 \\
(0.300)\end{array}$ & $\begin{array}{l}-0.002 \\
(0.024)\end{array}$ & $\begin{array}{l}-0.478 * \\
(0.262)\end{array}$ & $\begin{array}{l}0.006 \\
(0.064)\end{array}$ & $\begin{array}{l}-368.749 * * \\
(149.870)\end{array}$ & $\begin{array}{l}-0.067 \\
(0.061)\end{array}$ \\
\hline \multicolumn{7}{|l|}{ Region } \\
\hline $\begin{array}{l}\text { Stockholm } \\
\text { Malmoe }\end{array}$ & $\begin{array}{l}\text { Reference } \\
-0.135^{* * *} \\
(0.020)\end{array}$ & $\begin{array}{l}-0.028 * * * \\
(0.005)\end{array}$ & $\begin{array}{l}0.055^{*} \\
(0.031)\end{array}$ & $\begin{array}{l}-0.006 \\
(0.009)\end{array}$ & $\begin{array}{l}60.566 * * * \\
(21.127)\end{array}$ & $\begin{array}{l}-0.008 * * \\
(0.004)\end{array}$ \\
\hline
\end{tabular}


Table 10 (continued)

\begin{tabular}{|c|c|c|c|c|c|c|}
\hline $\begin{array}{l}\text { Method } \\
\text { Outcome }\end{array}$ & $\begin{array}{l}\text { OLS } \\
\text { Ln(income) }\end{array}$ & $\begin{array}{l}\text { OLS } \\
\text { Top income } \\
\text { percentile }\end{array}$ & $\begin{array}{l}\text { OLS } \\
\text { Ln(revenue) }\end{array}$ & $\begin{array}{l}\text { OLS } \\
\text { Incorporated } \\
\text { firm }\end{array}$ & $\begin{array}{l}\text { Tobit } \\
\text { Number of } \\
\text { employees }\end{array}$ & $\begin{array}{l}\text { OLS } \\
\text { Exit }\end{array}$ \\
\hline \multirow[t]{2}{*}{ Gothenburg } & $-0.033^{*}$ & $-0.031 * * *$ & $0.087 * * *$ & 0.009 & $57.666^{* * *}$ & $-0.017 * * *$ \\
\hline & $(0.018)$ & $(0.005)$ & $(0.028)$ & $(0.008)$ & (19.987) & $(0.004)$ \\
\hline \multirow[t]{2}{*}{ Other } & $-0.049 * * *$ & $-0.037 * * *$ & $0.060 * *$ & $0.070 * * *$ & $51.532 * * *$ & $-0.015 * * *$ \\
\hline & $(0.015)$ & $(0.004)$ & $(0.025)$ & $(0.007)$ & $(15.654)$ & $(0.003)$ \\
\hline \multicolumn{7}{|l|}{ Region of birth } \\
\hline Sweden & Reference & & & & & \\
\hline \multirow[t]{2}{*}{ Nordic countries } & 0.003 & 0.026 & -0.099 & -0.029 & 25.950 & 0.011 \\
\hline & $(0.056)$ & $(0.017)$ & $(0.089)$ & $(0.027)$ & $(40.386)$ & $(0.011)$ \\
\hline \multirow[t]{2}{*}{ EU15 } & -0.064 & -0.005 & 0.105 & 0.047 & 28.411 & 0.006 \\
\hline & $(0.074)$ & $(0.016)$ & $(0.128)$ & $(0.037)$ & (29.102) & $(0.017)$ \\
\hline \multirow[t]{2}{*}{ Europe } & -0.062 & 0.004 & -0.027 & $-0.050 * *$ & 123.464 & -0.014 \\
\hline & $(0.047)$ & $(0.011)$ & $(0.083)$ & $(0.020)$ & $(83.627)$ & $(0.010)$ \\
\hline \multirow[t]{2}{*}{ Africa } & -0.032 & 0.013 & 0.138 & -0.014 & 47.078 & 0.004 \\
\hline & $(0.123)$ & $(0.025)$ & $(0.141)$ & $(0.043)$ & $(44.688)$ & $(0.021)$ \\
\hline \multirow[t]{2}{*}{ North America } & $0.202 *$ & -0.004 & -0.153 & -0.045 & 40.201 & 0.002 \\
\hline & $(0.121)$ & $(0.031)$ & $(0.188)$ & $(0.062)$ & $(65.228)$ & $(0.027)$ \\
\hline \multirow[t]{2}{*}{ South America } & -0.185 & 0.026 & -0.025 & $-0.065^{* *}$ & 33.337 & $0.041 * *$ \\
\hline & $(0.123)$ & $(0.021)$ & $(0.133)$ & $(0.029)$ & $(41.533)$ & $(0.017)$ \\
\hline \multirow[t]{2}{*}{ Asia } & $-0.058 *$ & $0.015 * *$ & $0.351 * * *$ & $-0.033 * * *$ & $118.393 * * *$ & 0.001 \\
\hline & $(0.030)$ & $(0.006)$ & $(0.043)$ & $(0.012)$ & $(19.213)$ & $(0.006)$ \\
\hline \multirow[t]{2}{*}{ Oceania } & -0.221 & -0.041 & 0.147 & -0.091 & 100.800 & -0.017 \\
\hline & $(0.232)$ & $(0.032)$ & $(0.518)$ & $(0.063)$ & $(173.561)$ & $(0.048)$ \\
\hline \multirow[t]{2}{*}{ Soviet Union } & -0.402 & -0.003 & $-0.732 * * *$ & -0.082 & $-151.790^{* *}$ & 0.051 \\
\hline & $(0.274)$ & $(0.064)$ & $(0.259)$ & $(0.069)$ & $(69.001)$ & $(0.044)$ \\
\hline \multicolumn{7}{|l|}{ Industry } \\
\hline Personal and cultural services & Reference & & & & & \\
\hline \multirow[t]{2}{*}{ Agriculture } & $-0.205 * * *$ & $0.013 * * *$ & $0.256^{* * *}$ & $-0.024 * *$ & -19.062 & $-0.027 * * *$ \\
\hline & $(0.037)$ & $(0.005)$ & $(0.053)$ & $(0.010)$ & $(14.952)$ & $(0.008)$ \\
\hline \multirow[t]{2}{*}{ Manufacturing } & $-0.067 * *$ & $0.013 *$ & $0.490 * * *$ & $0.281 * * *$ & $47.711 * * *$ & 0.018 \\
\hline & $(0.029)$ & $(0.007)$ & $(0.048)$ & $(0.016)$ & $(13.834)$ & $(0.067)$ \\
\hline \multirow[t]{2}{*}{ Energy } & $0.662 * * *$ & $0.321 * *$ & $2.633 * * *$ & $0.485 * * *$ & 44.714 & $-0.026 * *$ \\
\hline & $(0.150)$ & $(0.128)$ & $(0.677)$ & $(0.083)$ & $(41.203)$ & $(0.010)$ \\
\hline \multirow[t]{2}{*}{ Construction and transportation } & $0.193 * * *$ & $0.025 * *$ & $1.018 * * *$ & $0.451 * * *$ & $81.492 * * *$ & $-0.026^{* * *}$ \\
\hline & $(0.031)$ & $(0.013)$ & $(0.061)$ & $(0.020)$ & $(12.070)$ & $(0.006)$ \\
\hline \multirow{2}{*}{$\begin{array}{l}\text { Retailing, communication, } \\
\text { hotel, and restaurants }\end{array}$} & $0.031 *$ & 0.001 & $0.812 * * *$ & $0.325 * * *$ & $86.183 * * *$ & $-0.040 * * *$ \\
\hline & $(0.016)$ & $(0.004)$ & $(0.025)$ & $(0.008)$ & $(10.559)$ & $(0.006)$ \\
\hline \multirow[t]{2}{*}{ Financial and business services } & $0.217 * * *$ & $0.057 * * *$ & $0.137 * * *$ & $0.163 * * *$ & 11.471 & $-0.068 * * *$ \\
\hline & $(0.016)$ & $(0.004)$ & $(0.022)$ & $(0.008)$ & $(7.066)$ & $(0.009)$ \\
\hline \multirow[t]{2}{*}{ Education and research } & $0.146 * * *$ & $0.031 * * *$ & $0.359 * * *$ & $0.184 * * *$ & $61.925^{* * *}$ & -0.059 *** \\
\hline & $(0.035)$ & $(0.011)$ & $(0.050)$ & $(0.018)$ & $(14.423)$ & $(0.008)$ \\
\hline \multirow[t]{2}{*}{ Health care } & $0.383 * * *$ & $0.061 * * *$ & $0.496^{* * *}$ & $0.086^{* * *}$ & $307.832 * * *$ & $-0.020 * * *$ \\
\hline & $(0.026)$ & $(0.008)$ & $(0.057)$ & $(0.012)$ & $(66.977)$ & $(0.006)$ \\
\hline
\end{tabular}


Table 10 (continued)

\begin{tabular}{|c|c|c|c|c|c|c|}
\hline $\begin{array}{l}\text { Method } \\
\text { Outcome }\end{array}$ & $\begin{array}{l}\text { OLS } \\
\text { Ln(income) }\end{array}$ & $\begin{array}{l}\text { OLS } \\
\text { Top income } \\
\text { percentile }\end{array}$ & $\begin{array}{l}\text { OLS } \\
\text { Ln(revenue) }\end{array}$ & $\begin{array}{l}\text { OLS } \\
\text { Incorporated } \\
\text { firm }\end{array}$ & $\begin{array}{l}\text { Tobit } \\
\text { Number of } \\
\text { employees }\end{array}$ & $\begin{array}{l}\text { OLS } \\
\text { Exit }\end{array}$ \\
\hline Public administration & $\begin{array}{l}-0.160 \\
(0.472)\end{array}$ & $\begin{array}{l}0.021 \\
(0.041)\end{array}$ & & $\begin{array}{l}-0.031 \\
(0.093)\end{array}$ & - & $\begin{array}{l}-0.151 * * * \\
(0.058)\end{array}$ \\
\hline Unknown & $\begin{array}{l}-0.024 \\
(0.026)\end{array}$ & $\begin{array}{l}0.030 * * * \\
(0.003)\end{array}$ & $\begin{array}{l}1.412 * * * \\
(0.392)\end{array}$ & $\begin{array}{l}-0.093 * * * \\
(0.005)\end{array}$ & $\begin{array}{l}184.989 * * \\
(82.234)\end{array}$ & $\begin{array}{l}0.007 \\
(0.007)\end{array}$ \\
\hline \multicolumn{7}{|l|}{ Previous labor market status } \\
\hline Wage-earner & Reference & & & & & \\
\hline In education & $\begin{array}{l}-0.073 * * \\
(0.031)\end{array}$ & $\begin{array}{l}0.045 * * * \\
(0.005)\end{array}$ & $\begin{array}{l}-0.089 * * \\
(0.045)\end{array}$ & $\begin{array}{l}-0.019 \\
(0.012)\end{array}$ & $\begin{array}{l}-9.115 \\
(16.043)\end{array}$ & $\begin{array}{l}-0.008 \\
(0.006)\end{array}$ \\
\hline Unemployed & $\begin{array}{l}-0.006 \\
(0.025)\end{array}$ & $\begin{array}{l}0.050 * * * \\
(0.004)\end{array}$ & $\begin{array}{l}-0.051 \\
(0.034)\end{array}$ & $\begin{array}{l}-0.044 * * * \\
(0.010)\end{array}$ & $\begin{array}{l}7.544 \\
(13.636)\end{array}$ & $\begin{array}{l}-0.041 * * * \\
(0.005)\end{array}$ \\
\hline Parental leave & $\begin{array}{l}0.037 \\
(0.028)\end{array}$ & $\begin{array}{l}0.059 * * * \\
(0.006)\end{array}$ & $\begin{array}{l}0.070 * \\
(0.041)\end{array}$ & $\begin{array}{l}0.045^{* * * *} \\
(0.012)\end{array}$ & $\begin{array}{l}9.172 \\
(12.172)\end{array}$ & $\begin{array}{l}0.004 \\
(0.005)\end{array}$ \\
\hline Other & $\begin{array}{l}-0.025 \\
(0.025)\end{array}$ & $\begin{array}{l}0.069 * * * \\
(0.004)\end{array}$ & $\begin{array}{l}0.098 * * * \\
(0.034)\end{array}$ & $\begin{array}{l}0.009 \\
(0.008)\end{array}$ & $\begin{array}{l}52.563 * * * \\
(13.390)\end{array}$ & $\begin{array}{l}-0.005 \\
(0.004)\end{array}$ \\
\hline Earnings prior to SE entry/1000 & $\begin{array}{l}0.002 * * * \\
(0.000)\end{array}$ & $\begin{array}{l}0.001 * * * \\
(0.000)\end{array}$ & $\begin{array}{l}0.002 * * * \\
(0.000)\end{array}$ & $\begin{array}{l}0.001 * * * \\
(0.000)\end{array}$ & $\begin{array}{l}0.186^{* * *} \\
(0.035)\end{array}$ & $\begin{array}{l}-0.000^{* * * *} \\
(0.000)\end{array}$ \\
\hline Regional unemployment (\%) /10 & $\begin{array}{l}-0.002 \\
(0.033)\end{array}$ & $\begin{array}{l}-0.019 * * \\
(0.009)\end{array}$ & $\begin{array}{l}-0.000 \\
(0.054)\end{array}$ & $\begin{array}{l}-0.024 \\
(0.015)\end{array}$ & $\begin{array}{l}42.693 \\
(32.596)\end{array}$ & $\begin{array}{l}0.006 \\
(0.008)\end{array}$ \\
\hline Constant & $\begin{array}{l}10.601 * * * \\
(0.295)\end{array}$ & $\begin{array}{l}-0.103 * \\
(0.057)\end{array}$ & $\begin{array}{l}4.590 * * * \\
(0.385)\end{array}$ & $\begin{array}{l}-0.569 * * * \\
(0.123)\end{array}$ & $\begin{array}{l}-533.661 * * * \\
(182.730)\end{array}$ & $\begin{array}{l}1.932 * * * \\
(0.062)\end{array}$ \\
\hline Observations & 102,458 & 102,458 & 93,050 & 118,565 & 94,838 & 106,704 \\
\hline$R^{2} /$ sigma & 0.287 & 0.214 & 0.521 & 0.278 & $\begin{array}{l}396.586^{* * *} \\
(44.890)\end{array}$ & 0.206 \\
\hline
\end{tabular}

Notes: All models include year dummies for the years 1996-2013. Robust standard errors in parentheses

$* p<0.1 ; * *<0.05 ; * * * p<0.01$ 


\section{Appendix 2}

Table 11 Descriptive statistics for self-employed at P10, P50, and P90 of the earnings distribution of the most recent year in selfemployment and with positive incomes

\begin{tabular}{lccc}
\hline & P10 & P50 & P90 \\
\hline Child at start & 63.1 & 64.6 & 74.4 \\
Young children & 64.9 & 64.4 & 67.5 \\
Total number of children $(\%)$ & & \\
0 & 31.3 & 28.0 & 20.3 \\
1 & 20.8 & 18.8 & 15.1 \\
2 & 33.6 & 38.5 & 50.6 \\
3 & 11.1 & 12.5 & 12.7 \\
& 2.7 & 2.0 & 1.2 \\
More than 4 & 0.5 & 0.1 & 0.1 \\
Age & 34.6 & 36.9 & 39.7 \\
Age at start & 33.3 & 34.2 & 36.1 \\
Observations & 2241 & 2240 & 2243 \\
\hline
\end{tabular}

Open Access This article is distributed under the terms of the Creative Commons Attribution 4.0 International License (http:// creativecommons.org/licenses/by/4.0/), which permits unrestricted use, distribution, and reproduction in any medium, provided you give appropriate credit to the original author(s) and the source, provide a link to the Creative Commons license, and indicate if changes were made.

\section{References}

Aldén, L. \& Hammarstedt, M. (2015). Exits from immigrant selfemployment: when, why and where to? Working Paper 2015: 14, Linnæus University, Centre for Labour Market and Discriminations Studies.

Andersson, G. (2000). The impact of labour-force participation on childbearing behaviour: pro-cyclical fertility in Sweden during the 1980s \& the 1990s. European Journal of Population, 16(4), 293-333. doi:10.1023/A:1006454909642.

Andersson Joona, P. (2010). Exits from self-employment. Is there a native-immigrant difference in Sweden? International Migration Review, 44(3), 539-559. doi:10.1111/j.17477379.2010.00817.x.

Andersson Joona, P. (2017). Are mothers of young children more likely to be self-employed? The case of Sweden. Review of Economics of the Household., 15(1), 307-333. doi:10.1007 /s11150-016-9349-6.

Andersson, P. (2008). Happiness and health: well-being among the self-employed. Journal of Socio-economics., 37(1), 213236. doi:10.1016/j.socec.2007.03.003.
Angelov, N. \& Karimi, A. (2012). Mothers' income recovery after childbearing. IFAU Working Paper, 2012:20. http://www. ifau.se/globalassets/pdf/se/2012/wp12-20-mothers-incomerecovery-after-childbearing.pdf.

Anxo, D., \& Ericson, T. (2015). Self-employment and parental leave. Small Business Economics, 45(4), 751-770. doi:10.1007/s11187-015-9669-6.

Asoni, A., \& Sanandaji, T. (2016). Identifying the effect of college education on business and employment survival. Small Business Economics, 46(2), 311-324. doi:10.1007/s11187015-9686-5.

Benz, M., \& Frey, B. S. (2008). Being independent is a great thing. Subjective evaluations of self-employment and hierarchy. Economica, 75(298), 362-383. doi:10.1111/j.14680335.2007.00594.x.

Boden, R. J. (1996). Gender and self-employment selection: an empirical assessment. Journal of Socio-Economics, 25(6), 671-682. doi:10.1016/S1053-5357(96)90046-3.

Boden, R. J. (1999). Flexible working hours, family responsibilities, and female self-employment. American Journal of Economics and Sociology, 58(1), 71-83. doi:10.1111 j.1536-7150.1999.tb03285.x.

Broussard, N. H., Chami, R., \& Hess, G. D. (2015). (Why) do selfemployed parents have more children? Review of economics of the Household, 13(2), 297-321. doi:10.1007/s11150-0139190-0.

Budig, M. J. (2006). Intersections on the road to self-employment: gender, family and occupational class. Social Forces, 84(4), 2223-2239. doi:10.1353/sof.2006.0082.

Budig, M. J., \& England, P. (2001). The wage penalty of motherhood. American Sociological Review, 66(2), 204-225.

Burke, A. E., FitzRoy, F. R., \& Nolan, M. A. (2002). Selfemployment wealth and job creation: the roles of gender, nonpecuniary motivation and entrepreneurial ability. Small Business Economics, 19(3), 255-270. doi:10.1023/A:1019698607772.

Carr, D. (1996). Two paths to self-employment? Women's and men's self-employment in the United States, 1980. Work and Occupations, 23(1), 26-53. doi:10.1177 /0730888496023001003.

Dawson, C., Holtz, A., \& Latreille, P. L. (2014). Individual motives for choosing self-employment in the UK: does region matter? Regional Studies, 48(5), 804-822. doi:10.1080 /00343404.2012.697140.

Ekelund, J., Johansson, E., Järvelin, M.-J., \& Lichtermann, D. (2005). Self-employment and risk aversion - evidence from psychological test data. Labour Economics, 12(5), 649-659. doi:10.1016/j.labeco.2004.02.009.

Fairlie, R. W., \& Robb, A. (2007). Why are black-owned businesses less successful than white-owned businesses? The role of families, inheritances, and business human capital. Journal of Labor Economics, 25(2), 289-323. doi:10.1086/510763.

Gash, V. (2009). Sacrificing their careers for their families? An analysis of the penalty to motherhood in Europe. Social Indicators Research, 93(3), 569-586. doi:10.1007/s11205008-9429-y.

Gimenez-Nadal, J., Molina, A., \& Ortega, R. (2012). Self-employed mothers and the work-family conflict. Applied Economics, 44(17), 2133-2147. doi:10.1080/00036846.2011.558486.

Gurley-Calvez, T., Biehl, A., \& Harper, K. (2009). Time-use patterns and women entrepreneurship. American Economic Review: Papers and Proceedings, 99(2), 139-144. 
Henley, A. (2005). Job creation by the self-employed: the roles of entrepreneurial and financial capital. Small Business Economics, 25(2), 175-196. doi:10.1007/s11187-004-6480-1.

Holtz-Eakin, D., Joulfaian, D., \& Rosen, H. S. (1994). Sticking it out: entrepreneurial survival and liquidity constraints. Journal of Political Economy, 102(1), 53-75.

Hughes, K. D. (2006). Exploring motivation and success among Canadian women entrepreneurs. Journal of Small Business \& Entrepreneurship, 19(2), 107-120. doi:10.1080 /08276331.2006.10593362.

Hundley, G. (2000). Male/female earnings differences in selfemployment: the effects of marriage, children, and the household division of labor. Industrial and Labor Relations Review, 54(1), 95-114. doi:10.1177/001979390005400106.

Hundley, G. (2001). Why women earn less than men in selfemployment. Journal of Labor Research, 22(4), 817-829. doi:10.1007/s12122-001-1054-3.

Hurst, L., \& Lusardi, A. (2004). Liquidity constraints, household wealth, and entrepreneurship. Journal of Political Economy, 112(2), 319-347. doi:10.1086/381478.

Johansson Sevä, I., \& Öun, I. (2015). Self-employment as a strategy for dealing with the competing demands of work and family? The importance of family/lifestyle motives. Gender, Work and Organization, 22(3), 256-272. doi:10.1111/gwao.12076.

Kangasharju, A., \& Pekkala, S. (2002). The role of education in self-employment success in Finland. Growth and Change., 33, 216-237. doi:10.1111/0017-4815.00188.

Lazear, E. P. (2004). Balanced skills and entrepreneurship. American Economic Review: Papers and Proceedings, 94(2), 208-211.

Lin, Z., Picot, G., \& Compton, J. (2000). The entry and exit dynamics of self-employment in Canada. Small Business Economics, 15(2), 105-125. doi:10.1023 /A:1008150516764.

Lombard, K. V. (2001). Female self-employment and demand for flexible, nonstandard work schedules. Economic Inquiry, 39(2), 214-237. doi:10.1111/j.1465-7295.2001.tb00062.x.

Lundberg, S., \& Rose, E. (2000). Parenthood and the earnings of married men and women. Labour Economics, 7(6), 689-710. doi:10.1016/S0927-5371(00)00020-8.

Mångs, A. (2013). Self-employment in Sweden: a gender perspective, Linnaeus University dissertations no. 146/213, Växjö: Linnaeus University Press.

Marshall, M. I., \& Flaig, A. (2014). Marriage, children, and selfemployment earnings: an analysis of self-employed women in the US. Journal of Family and Economic Issues, 35(3), 313-322. doi:10.1007/s10834-013-9373-0.

Millán, J. M., Congregado, E., \& Román, C. (2012). Determinants of self-employment survival in Europe. Small Business Economics., 38, 231-258. doi:10.1007/s11187-010-9260-0.

Noseleit, F. (2014). Female self-employment and children. Small Business Economics, 43(3), 549-569. doi:10.1007/s11187014-9570-8.

Parker, S. C. (2004). The economics of self-employment and entrepreneurship. Cambridge: University Press.

Rey-Martí, A., Porcar, A. T., \& Mas-Tur, A. (2015). Linking female entrepreneurs' motivation to business survival. Journal of Business Research., 68(4), 810-814 http://dx. doi.org/10.1016/j.jbusres.2014.11.033.

Rønsen, M. (2014). Children and family: a barrier or an incentive to female self-employment in Norway. International Labour Review, 153(2), 337-349. doi:10.1111/j.1564-913 X.2014.00207.x.

Rybczynski, K. (2015). What drives self-employment survival for women and men? Evidence from Canada. Journal of Labor Research, 36(1), 27-43. doi:10.1007/s12122-014-9194-4.

S C B ( $\left.\begin{array}{llll}2 & 0 & 1 & 5\end{array}\right)$. h t t p://www.scb.se/s _ / H ittastatistik/Artiklar/Giftermalen-okade-under-2014/.

Simoes, N., Moreira, S., \& Crespo, N. (2015). Individual determinants of self-employment entry-what do we really know? Journal of Economic Surveys, 30, 1-24. doi:10.1111 /joes.12111.

Taniguchi, H. (2002). Determinants of women's entry into selfemployment. Social Science Quarterly, 83(3), 875-893.

Taylor, M. P. (1999). Survival of the fittest? An analysis of selfemployment duration in Britain. Economic Journal, 109(454), 140-155. doi:10.1111/1468-0297.00422.

van der Sluis, J., van Praag, M., \& Vijverberg, W. (2008). Education and entrepreneurship selection and performance: a review of the empirical literature. Journal of Economic Surveys, 22(5), 795-841. doi:10.1111/j.14676419.2008.00550.x.

Waldfogel, J. (1998). Understanding the "family gap" in pay for women with children. Journal of Economic Perspectives, 12(1), 137-156.

Wellington, A. J. (2006). Self-employment: the new solution for balancing family and career? Labour Economics, 13(3), 357386. doi:10.1016/j.labeco.2004.10.005.

Williams, D. R. (2004). Effects of childcare activities on the duration of self-employment in Europe. Entrepreneurship Theory and Practice., 28(5), 467-485. doi:10.1111/j.15406520.2004.00058.x. 